PUBLISHED BY THE AMERICAN MUSEUM OF NATURAL HISTORY CENTRAL PARK WEST AT 79TH STREET, NEW YORK, NY 10024 Number 3601, 26 pp., 7 figures, 1 table

December 12, 2007

\title{
Morphological Diversity in the Postcranial Skeleton of Casamayoran (?Middle to Late Eocene) Notoungulata and Foot Posture in Notoungulates
}

\author{
BRUCE J. SHOCKEY ${ }^{1}$ AND JOHN J. FLYNN²
}

\begin{abstract}
Appendicular skeletons of isotemnid notoungulates are described from Cañadón Vaca (Vacan "subage", Casamayoran South American Land Mammal "Age", ?middle to late Eocene). Simpson documented three of these, Thomashuxleya externa, Anisotemnus distentus, and Pleurostylodon similis, some 70 years ago, in fashioning a composite isotemnid skeleton, but he did not emphasize their differences from one another. We note variation, especially in the forelimb, that appears to be functionally significant as well as phylogenetically informative. For example, the downwardly curved olecranon, ventrally concave bowing of the ulnar shaft, and orthogonally directed articulation of the elbow joint suggest an erect forelimb stance in Thomashuxleya externa, whereas the forelimbs of Anisotemnus distentus and Pleurostylodon similis show indications of a crouching posture, including ventrally convex bowing of the ulnar shaft with a slight upward curvature of the olecranon, and an elbow joint in which the antebrachium rotated obliquely relative to the humerus. Articular facets on the proximal carpals suggest that the manus of Anisotemnus was habitually extended, indicating a plantigrade stance of the forelimb. Although none of these three taxa have associated hindfoot material, all known Vacan notoungulate astragali have shallow trochlea, welldeveloped and deep grooves for the flexor hallucis longus, which are separated from the trochlea by a fossa that contains a superior astragalar foramen. An isolated notoungulate pes, not referred to any of the three taxa above, appears to be pentadactyl, having a distinctive, divergent tarsometatarsal joint for its hallux. It also has a shallow trochlea, an astragalar foramen, and a flexor groove, indicating limited rotation of the upper ankle joint. Indeed, a survey of known Casamayoran-aged notoungulate astragali indicates that most taxa had limited mobility at the tibioastragalar joint, in stark contrast to post-Eocene faunas in which nearly all the ungulates had greater rotation of the upper ankle joint and were subcursorial, as evidenced by their longer and

${ }^{1}$ Department of Biology, Manhattan College, New York, NY 10471 (bruce.shockey@manhattan.edu) and Division of Paleontology, American Museum of Natural History.

${ }^{2}$ Division of Paleontology, American Museum of Natural History (jflynn@amnh.org).
\end{abstract}


deeper trochlear articulation and loss of the astragalar foramen. We suggest that the change from ambulatory- to subcursorial-dominated ungulate faunas across the Eocene-Oliogocene boundary mirrors the changes from brachydont to hypsodont faunas over the same time. Decreased temperatures and rainfall resulting in more open habitats may be related to both morphological evolutionary patterns.

\section{INTRODUCTION}

Little has changed since Simpson (1936a: 1) remarked, "The skeleton of South American ungulates has been practically unknown for any stage before the Deseado" (Deseadan South American Land Mammal "Age" [SALMA], late Oligocene). His contribution regarding the postcranium of an Eocene (Casamayoran SALMA) "isotemnid" (order Notoungulata) remains a nearly singular example of a detailed analysis of a preDeseadan South American notoungulate skeleton.

Although both the feasibility and merit of Simpson's accounts (1936a, 1967) of the Casamayoran isotemnid postcrania might be questioned, his goal clearly was to document the morphology of an idealized isotemnid skeleton. To do so, he used the remains of three individuals representing three different taxa to describe a composite notoungulate skeleton. The taxa included Thomashuxleya externa, a second species that he did not specify (but we refer to Anisotemnus distentus), and a species of Pleurostylodon that later would be referred to $P$. simulis in Simpson's final attempt to sort out the taxonomic status of Casamayoran istotemnids (Simpson, 1967). Simpson figured the entire composite skeleton (Simpson, 1935, 1936a, 1967) but not individual elements, nor did he provide any metric data for the elements (although he did provide some unitless ratio indices). Because his goal was to describe an idealized, generalized isotemnid skeleton, he did little in the way of differentiating the morphology of the three taxa from one another. Instead, he emphasized the similarity among them, noting that the "structure is essentially the same in all with differences apparently of not more than generic value" (Simpson, 1936a: 2, 1967: 153). Although such a method may be useful in estimating the form of a hypothetical ancestor, the character analysis was not done within an explicit phylogenetic framework, and thus it has the serious disadvantage of obscuring any locomotor or taxonomic differences among the three forms,

The purpose of the current work is to provide greater understanding of the postcranial skeletal morphology of these three isotemnids. Also, additional specimens of Casamayoran isotemnids are described here for the first time, providing the first informative record of the pes of any pre-Deseadan notoungulate. Description of this pes helps document the apparently plantigrade pedal condition of an "archaic" (basal) notoungulate and provides an opportunity to investigate the transition from plantigrady to digitigrady in this major lineage of extinct, endemic South American ungulates.

\section{OVERVIEW OF \\ THE CASAMAYORAN SALMA}

Carlos Ameghino discovered the beds that would serve as the type locality for Casamayoran during the austral summer of 1894-1895, in Patagonia, along the Gulfo San Jorge, near Punta Casamayor (Simpson, 1984). However, the distinctiveness of this fauna was not recognized until 1899, as Carlos and his elder brother, Florentino, initially thought that fossils from Punta Casamayor were of Deseadan age ("Couches a Pyrotherium" in their terminology [F. Ameghino, 1895]). Therefore, the first descriptions of a variety of Casamayoran fossils were included in F. Ameghino's (1897) second contribution regarding the Deseadan SALMA. Later, however, Carlos discovered Casamayoran fossils at the Gran Barranca in their stratigraphic context, below and stratigraphically discordant from those assigned to the Deseadan. The superpositional context was now clear, so he wrote his brother in 1899, "It turns out what we have been calling the Pyrotherium fauna according to new observations is, in reality, the succession of two different faunas, separated by an enormous interval of time" (translated from Spanish by Simpson, 1984: 71). Carlos proposed to name it the Notostylops fauna, in 
reference to a common taxon there. Thus, it was designated as the Notostylopéen by the Ameghinos (F. Ameghino, 1906), but soon thereafter was given the geographically based and currently recognized name, Casamayoran (Gaudry, 1906).

Although F. Ameghino (1906) regarded the Casamayoran SALMA as Cretaceous in age, Gaudry (1906) (and everyone else since) has considered it to be Eocene, usually early Eocene (e.g., Gaudry, 1906; Simpson, 1940; Flynn and Swisher, 1995). Recently, however, work at the Gran Barranca suggests that the Casamayoran SALMA, or at least the Barracan part of it, may be as young as late Eocene (Kay et al., 1999).

George Gaylord Simpson and his small crew collected numerous Casamayoran fossils during the Scarritt Expeditions to Patagonia in the austral summers of late 1930-early 1931 and 1933-1934. Most of these came from two localities, Colhue Huapi, at the Gran Barranca, Chubut, Argentina, and Cañadón Vaca, which lies some $60 \mathrm{~km}$ northeast of the Gran Barranca in badlands having drainage into the Río Chico (Simpson, 1948: fig. 1, map). Much of the fauna from these two localities has been documented in Simpson's two-part work titled The Beginning of the Age of Mammals in South America" (Simpson, 1948, 1967).

Whereas Simpson (1948, 1967) described the individual taxa of the Casamayoran, Cifelli (1985) provided an analysis of the overall faunal composition. He found the Casamayoran faunas of the Gran Barranca and Cañadón Vaca to be "strikingly dissimilar" (Cifelli, 1985: 16). Of the 41 species that had sufficient morphological and stratigraphic data to be included in the analysis, only 4 were considered to be common to both regions (this excluded one Cañadón Vaca locality that Cifelli [1985] judged to be the same age as that of the Casamayoran fauna of the Gran Barranca). The generic and specific indices of faunal similarity between the Gran Barranca Casamayoran and Cañadón Vaca were considerably lower than indices of faunal similarity derived from different North American land mammal faunas assigned to the same North American Land Mammal "Age'. Thus, Cifelli (1985) proposed to subdivide the Casamayo- ran into temporally distinct "subages", the Barrancan and the somewhat older Vacan. However, absolute ages of these or any other Casamayoran locality remained unresolved until recently.

Kay et al. (1999) reported radioisotopic age determinations, complemented by paleomagnetic stratigraphy, that yielded an age estimate for the Barrancan "subage" of 35,34 to $36.62 \mathrm{Ma}$, placing it in the late Eocene, some 15 to 20 million years younger than previously thought. Flynn et al. (2003) raised technical objections to this interpretation and suggested a more conservative minimum age estimate of $38 \mathrm{Ma}$. Nevertheless, such a young age estimate for the Casamayoran implies that a huge temporal gap remains in the fossil record of the early and middle Eocene of South America, even if the Vacan "subage" of the Casamayoran is eventually determined to be significantly older than the Barrancan. Most strikingly, even though Barrancan and Vacan assemblages are distinct, their differences are at relatively low taxonomic levels, few major groups disappear or originate between them, and the morphology of taxa within higher level clades appears to change very little across this potentially long time span. The temporal extent of this relative stasis is unknown, since the upper age limit of the Riochican (the SALMA that precedes the Vacan "subage") remains unknown. The Riochican has been shown to be fatunistically more similar to the Vacan "subage", than the Vacan is to the Barracan "subages" (Simpson coefficients were 47 for the Riochican/Vacan compared to 29 for the Vacan/Barrancan; Cifelli. 1985). The Riochican SALMA has long been regarded as being Paleocene (Patterson and Pascual, 1972; Flynn and Swisher 1995; Marshall et al., 1997); however, it has only been radiometrically constrained from below, such that it is only known that it must be younger than $63 \mathrm{Ma}$ (Marshall et al., 1997). If it turns out that the Riochican is indeed Paleocene, then the relative stasis from the Riochican through the Bartacan "subage" may have extended over a period greater than 15 million years. An alternative hypothesis is that the Riochican is actually of Eocene age, and thus the length of stasis and the pre-Barrancan depositional hiatus would be shorter than supposed. 
Whereas a late Eocene age for at least the later part of the Casamayoran opens a preBarrancan gap in the record, it simultaneously crowds the currently undated Mustersan and Divisidaran SALMAs between it and the Tinguirirican SALMA, whose upper limit is radioisotopically constrained at $31.5 \mathrm{Ma}$ (Flynn et al., 2003). This implies that rapid changes occurred in South American faunas from the late Eocene to the early Oligocene (Kay et al., 1999; Flynn et al., 2003). These changes are conspicuous both taxonomically and in the dental evolution that occurred across diverse clades.

Whereas Mustersan and older faunas are dominated by herbivores having low crowned (brachydont) teeth, Tinguirirican and younger faunas are dominated by high crowned (hypsodont and/or hypselodont) taxa (Wyss et al., 1994: Kay et al., 1999; Flynn et al. 2003). The upward revision of the ages of the Casamayoran, Mustersan, and Divisideran, and the well-constrained younger limit of the age of the Tinguirirican, implies a rapid change from browsing-dominated faunas to grazing faunas. This change occurred during the late Eocene to early Oligocene cooling and drying (Prothero, 1994), which may be related to the development of circum-Antarctic currents that began as a result of the separation of South America from the Antarctic continent and the subsequent deepening of the Drake Passage (Kennett, 1977; Kay et al, 1999; Lawver and Gahagan, 2003; Flynn et al., 2003). Available data imply a history of late Eocene and older faunas being composed mostly of browsers, while by the early Oligocene (e.g., Tinguirirican SALMA) grazers dominated temperate South American faunal assemblages. Hypsodont mammals of post-Eocene faunas of South America included diverse taxa, such as argyrolagid marsupials, xenarthrans, and some rodents; however, most of the hypsodont taxa were notoungulates.

\section{Casamayoran NotoUngulata}

In his initial description of Casamayoran fossils (initially thinking that they were of Deseadan age), Ameghino (1897) first recognized several of the major groups of notoungu- lates (although it is striking that he never recognized Notoungulata itself as a distinct group). Of these, the Isotemnidae are the focus of the current study due to the availability of postcranial specimens and the apparently basal position of isotemnids within Notoungulata (e.g., as a hypothetical ancestor to advanced Toxodontia; Simpson, 1967; Cifelli, 1993).

As anatomically generalized and early appearing notoungulates, isotemnids have always been considered to be basal to at least some groups of more morphologically advanced groups of notoungulates, For example, Ameghino (1897) thought that isotemnids were ancestral to homalodotheriids and leontiniids. He placed some species of the larger genera (Thomashuxleya, Anisotemmus, and "Proasmodus" [= Periphragnis], now generally recognized as being larger bodied isotemnids) in the Homalodotheriidae, as he thought these genera to have been ancestral to the Santacrucian taxon Homalodotherium (Ameghino, 1906). Simpson (e.g., 1936a) initially supported a special relationship among the isotemnids and homalodotheriids by recognizing the "Entelonychia", a group that included notostylopids, isotemnids, and homalodotheriids. Later (Simpson, 1967), he noted that the generalized morphology of isotemnids did not exclude them from being ancestral to notohippids, leontiniids, and toxodontids. $\mathrm{He}$ redefined the family Isotemnidae, "mostly by primitive characters, a procedure which is not wholly satisfactory but to which there seems to be no good alternative in this case" (Simpson, 1967: 118). He did recognize the accessory cuspule of the molar trigonids as a possible derived character for isotemnids. However, the diagnostic value of this feature may be limited, since it is absent in some isotemnids (e.g., Periphragnis and Distylophorus) and present in some taxa generally considered to be oldfieldthomasiids (e.g. Colbertia and Maxschlosseria) (Cifelli, 1993).

The notion that isotemnids were the nearest outgroup to leontiniids, notohippids, and toxodontids. as well as homalodotheriids, received some support in the phylogenetic analysis of Cifelli (1993), although the alternative possibility that isotemnids and homalodotheriids together formed a monophyletic 
group distinct from all other notoungulates was supported by the unmodified strict consensus tree. Cifelli's (1993) work remains the only phylogenetic analysis of the interfamilial relationships among notoungulates, Characters used in that analysis were mostly craniodental, but one manual and five tarsal characters were included.

Whereas most elements of the postcranial skeleton of pre-Deseadan notoungulates remain poorly known, isolated tarsal elements have been reasonably well documented (Ameghino, 1904; Cifelli, 1983; Bergqvist, 1996). These, however, have lacked clear associations with dental material, the usual basis for diagnosing fossil mammal species. To establish associations between these elements, Cifelli (1983) and Bergqvist (1996) attempted to correlate the size of proximal tarsals with dentitions from discrete localities of the middle to late Paleocene, Itaboraí, Brasil. These attempts yielded credible associations, although specimens that directly associate dental and postcranial material in single individuals would provide the only definitive taxonomic link between these elements.

In contrast, Ameghino (1904) did not indicate his method of assigning the tarsal elements to a particular taxon. Simpson regarded Ameghino's specific determinations as "totally unreliable and the generic hardly less so" (Simpson, 1967: 193-194), but discoveries of associated postcranials with cranial material provide some vindication for Ameghino's associations (e.g., Scott, 1912a for Nesodon and Adinotherium; Chaffee, 1952 for Rhynchippus pumilus; Sydow, 1988 and Shockey et al., 2007 for Trachytherus), Presumably, Carlos Ameghino made many of the initial taxonomic identifications in the field, but since he did not use sophisticated collecting techniques he typically was unable to recover broken long bones, but he generally collected only the durable teeth and tarsals of individual specimens. Regardless of the quality of the initial identifications, the Ameghinos were able to document Casamayoran astragali representing at least 22 distinct operational taxonomic units (Ameghíno, 1904).

Improving our knowledge of postcranial skeletons of early notoungulates can greatly enhance phylogenetic and paleoecological studies. Indeed, few postcranial data have been included in previous phylogenetic analyses of notoungulates of any age, with the interfamilial analysis of Cifelli (1993) being exceptional in this regard. Also, knowledge of the postcranial skeleton frequently yields functionally significant information.

\section{MATERIALS AND METHODS}

The basis of this study is the collection of fossils in the AMNH obtained by G.G. Simpson and crew at the Casamayoran SALMA locality Cañadón Vaca during the First Scarritt Expedition of 1930-1931. Comparative materials included some specimens from the Casamayoran horizon at Colhué Huapi (the Gran Barranca), also collected by Simpson, and elements from Mustersan SALMA assemblages, including casts of specimens collected by $\mathrm{S}$. Roth, the originals of which are curated in the Museo de la Plata collections.

Traditional family names are generally used, with the caveat that the interfamilial relationships among notoungulates are not well understood or rigorously tested, and some almost surely represent basal, paraphyletic taxa (e.g., Isotemnidae). However, until these detailed phylogenetic analyses are performed, it is pointless to add to the confusion by inventing provisional and likely unstable nomenclature.

To facilitate discrimination between taxa, individual taxa (and even specimens) are described separately. However, the figures and tables are organized by skeletal elements to aid comparisons of morphological features between the elements.

The following institutional abbreviations are used throughout this paper: $\mathrm{AMNH}$, American Museum of Natural History; MLP, Museo de La Plata, La Plata, Argentina.

\section{SYSTEMATIC PALEONTOLOGY AND COMPARATIVE ANATOMY}

FAMILY ISOTEMNIDAE AMEGHINO, 1897

Anisotemnus distentus (Ameghino, 1901)

Originally, Ameghino described this as a species of Isotemnus, but he later (Ameghino, 
1902) decided it pertained elsewhere, creating the new generic name Anisotemnus ("not Isotemnus") for it. Simpson (1967) recognized A. distentus as a valid taxon and provided a generic diagnosis, but he confessed that the genus "did not seem to differ in any readily diagnostic way from Thomashuxleya...or Pleurostylodon" (Simpson, 1967: 137). Nevertheless, its intermediate size between species referred to Thomashuxleya and those to Pleurostylodon makes $A$. distentus readily distinguishable, since it is the only Casamayoran isotemnid of this size.

In his initial description of the partial skeleton here referred to Anisotemnus, Simpson (1938) thought that it might represent a small species of Thomashuxleya. One of the few editorial changes Simpson (1967) made relative to his 1938 account of the idealized or composite isotemnid skeleton was his suggestion that his "specimen B" (AMNH 28906) might be referable to Anisotemnus.

Anisotemnus, however, had not been reported previously from Cañadón Vaca. Simpson (1967) did not include any Cañadón Vaca specimens in the hypodigm of $\mathrm{Ani}$ sotemmus, and Cifelli (1985) did not list this taxon from Cañadón Vaca in his faunal analysis. We note, however, two lower molars from Cañadón Vaca in the AMNH collection that are referable to Anisotemnus. AMNH 28648 is an $\mathrm{m} 3$ having mesial-distal and transverse dimensions of 27.9 and $14.5 \mathrm{~mm}$, respectively. These are smaller than any of the $\mathrm{m} 3 \mathrm{~s}$ of Thomashuxleya and larger than those of Pleurostylodon, but they are of similar dimensions to Anisotemnus specimens reported by Simpon (1967) and data obtained in the present study. Given this dental evidence of the occurrence of Anisoteminis at Canadón Vaca, combined with the presence of an isotemnid skeleton intermediate in size between that of Thomashuxleya externa and Pleurostylodon similis, we refer this suite of materials below to Anisotemnus distentus.

Material: All specimens referred here to Anisotemnus are from Cañadón Vaca ("Vacan" "subage" of the Casamayoran) and were collected by G.G. Simpson and crew in the austral summer of 1930-1931: AMNH 28648, left jaw fragment with erupted but unworn m3; AMNH 28664, heavily worn left p4 or ml; AMNH 28906, partial skeleton including the right scapula, right and left humerus, ulna, radius, and manus, as well as much of the axial skeleton; AMNH 28647, distal left radius, scaphoid, lunar, trapezoid, Mc I-V (distal end of Mc V missing), two indeterminate phalanges, and some sesamoids.

Description: The scapula of Anisotemnus (fig. 1) is similar to that of Thomashuxleya externa in general form and in details of the acromion. The scapular blade is ovoid, rather than triangular, with the lateral border being fairly straight, whereas the anterior border is strongly convex. The supraspinous fossa is much larger than the infraspinous fossa, with about twice the surface area. The spine is badly damaged, but the region near the glenoid is preserved well enough to show that it was well elevated above the blade. The acromial angle is developed into a distinct process, giving the acromion a forked appearance similar to that seen in Santacrucian interatheriids (Sinclair, 1909). The acromion, however, extends farther beyond the glenoid border in Anisotemnus than in the Santacrucian interatheriids. The spine is too damaged to determine if there were any other metacromia (e.g., as occurs in the Santacrucian toxodontids Nesodon and Adinotherium, which have two [see Scott, 1912a: pls. XXII.1, XXVII.8]). The glenoid is teardrop-shaped, with the apex directed toward the well-developed and recurved coracoid process.

The right humerus of Anisotemnus is extremely well preserved (fig. 2). The greater tubercle is broad but not exceedingly high. The greater tubercle and the large, bulbous lesser tubercle together form a well-defined bicipital groove. The crest of the lesser tubercle forms a sharply defined, raised posteromedial lip of the shaft that terminates at a raised tuberosity, the likely site of the teres major muscle insertion. Lateral (deltoid) and medial (pectoral) crests unite at a point more than halfway down the shaft. The supinator crest is bladelike and conspicuous. An entepicondylar foramen pierces the moderately developed medial epicondylar process. A common radial-ulnar fossa occurs just proximal to the capitulum. 


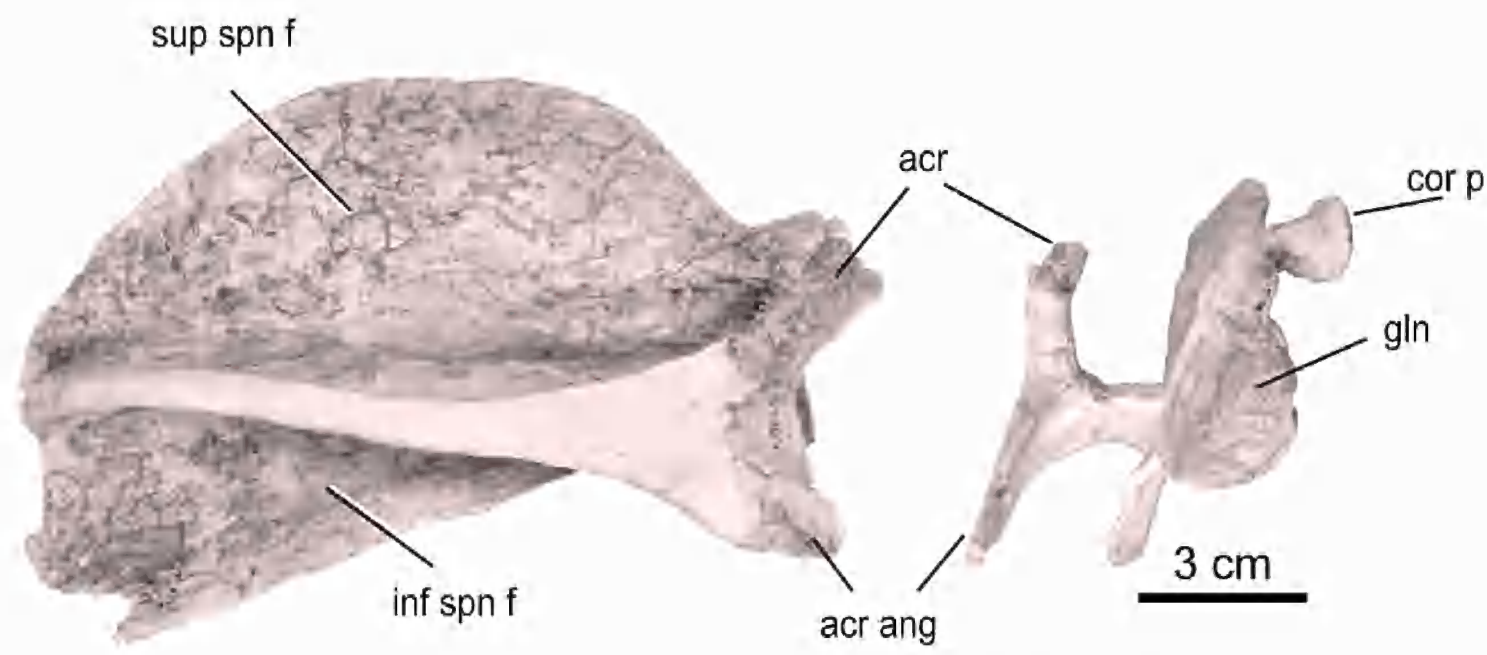

Fig. 1. Scapula of Anisotemmus distentus, AMNH 28906. Left, lateral view; right, distal view. Abbreviations: acr, acromion; acr ang, acromial angle; cor p, coracoid process; gln, glenoid fossa; inf spn $\mathrm{f}$, infraspinous fossa; sup spn f, supraspinous fossa.

The elbow articular region of the humerus has a distinctive, subspherical capitulum having a long axis that lies in a dorsoventral direction, suggesting parasagittal rather than rotary movements. The trochlear groove is deep, being bordered by a large, discoid medial flange. Whereas only a medial crest buttresses the ulna on the anterior side, both medial and lateral crests form a deep groove for the ulna posteriorly. The olecranon fossa is deep; however, the perforation appears to be due to breakage. Nevertheless, little bone separated the olecranon fossa from the antebrachial fossa of the anterior surface.

As in the antebrachia of all known notoungulates, the ulna and radius are separate elements (fig. 3). The ulnar shaft is strongly excavated on the lateral side, such that the midshaft region forms a " $\mathrm{C}$ " in cross section. The olecranon is fairly long and somewhat inturned, although not to the extent seen in the Deseadan mesotheriid Trachytherus (Shockey et al., 2007). The olecranon process is excavated on the medial side, forming a cavity that presumably was occupied by digital and wrist flexor muscles in life. The trochlear notch forms a broad crescent, terminating in a modestly tall coronoid process, which appears somewhat asymmetric due to the large size of the radial notch. The shaft does not taper distally, but instead there is some broadening on the distomedial surface, formed by what appears to be a pronator crest. The distal region of the ulna is damaged, except the styloid process, which is preserved in one of the ulnae.

As Simpson (1936a) noted, the radial shaft is curved, although curvature of the right side may be exaggerated by postmortem damage. In addition to being less circular than the proximal radius of Homalodotherium, as Simpson (1936a) observed, a conspicuous capitular eminence (fig. 3D) defines a notch on the dorsal (pronated) side of the proximal radius that, in anatomical position, wraps around the dorsoventrally oriented capitulum of the humerus. This form provides both precision of movement and a mechanical restraint against extreme supination. In addition to the articular surface on the ventral side of the proximal end of the radius (the ulnar facet), there is a smooth surface of the dorsolateral circumradial region suggestive of an articular facet. This facet has been directly observed in various notoungulates in which there is an articulation of the proximal radius with an elbow sesamoid, such as in the basal toxodontid Nesodon (Scott, 1912a) and the mesotheriid typotheres Trachytherus and Plesiotypotherium (Shockey et al., 2007). The radial tuberosity is somewhat elongated, commencing near the proximal ulnar facet 


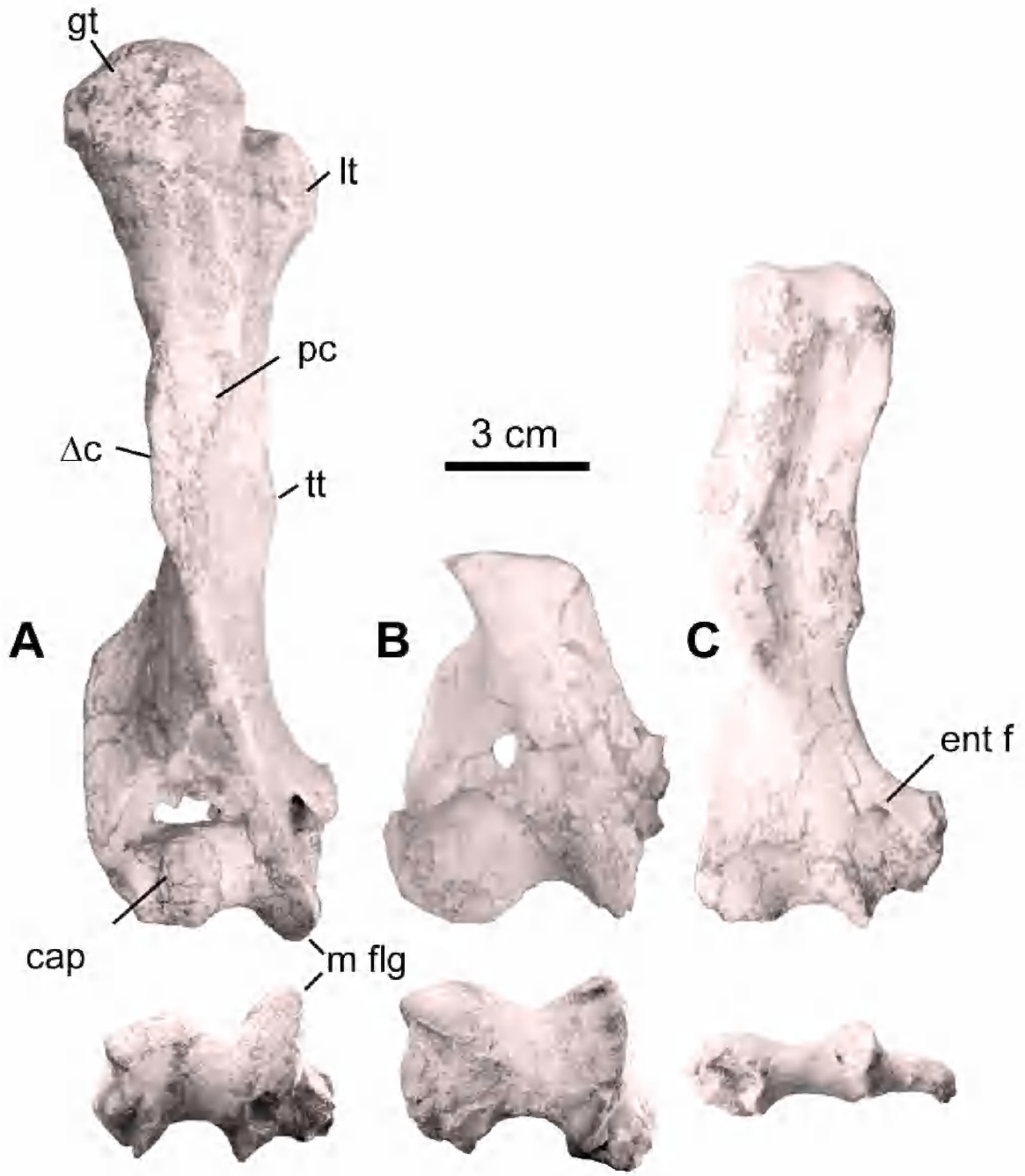

Fig. 2. Isotemnid humeri from Cañadón Vaca, Casamayoran SALMA (Vacan "subage"). Anterior (above) and distal (below) view of humeri of A, Ansiotemnus distentus, AMNH 28906; B, Thomashuxleya extena, AMNH 28653; and C, Plexotemnus similis, AMNH 28904. Scale bar applies to all. Panels A and B show right humeri and panel $\mathrm{C}$ shows a left humerus (but digitally reversed for ease of comparison). Abbreviations are: cap, capitulum; $\Delta \mathrm{c}$, deltoid crest; ent $\mathrm{f}$, entepicondylar foramen gt, greater tubercle; lt, lesser tubercle; $\mathrm{m}$ flg, medial flange; $\mathrm{pc}$, pectoral crest; $\mathrm{tt}$, teres tubercle.

and extending about $3 \mathrm{~cm}$ down the shaft, with its ridge forming a double crescent. The width of the radial shaft increases distally where a bladelike extension on the dorso-ulnar side overlies a triangular articulation for the distal ulna. The diaphysis and epiphysis are fused, but their border is still evident at the distal radius. The epiphysis supports a single, longitudinal dorsal tubercle that terminates at the radiocarpal joint near the articulation for the scaphoid and lunar.
Simpson's (1936a) description of the isotemnid manus was based on AMNH 28906 (Anisotemnus distentus), since the manus of his "specimen A" (Thomashuxleya) was badly damaged. Details are not repeated here, but its major features are summarized. Also, whereas Simpson compared this manus to that of Homalodolotherium, we compare it to that of a putative sister taxon of Notoungulata, Arctocyon (AMNH 16543), since that of Anisotemnus appears to be the 

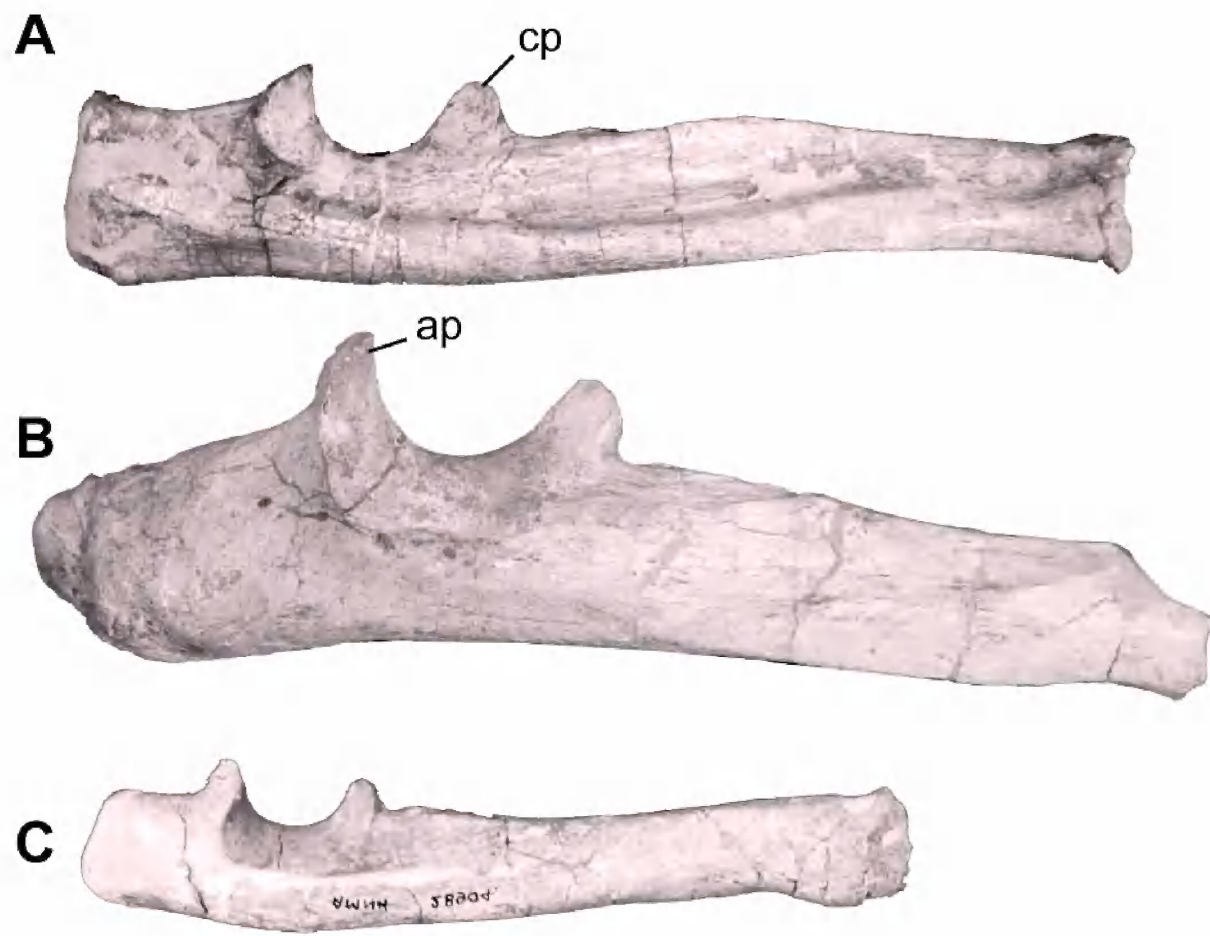

\section{$3 \mathrm{~cm}$}

D

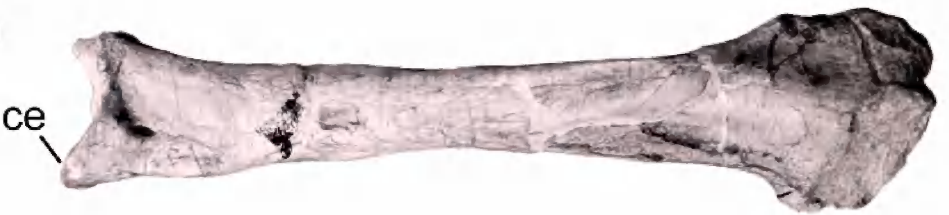

E

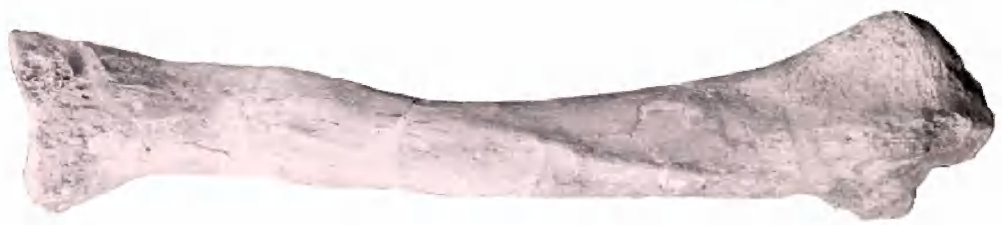

$\mathbf{F}$

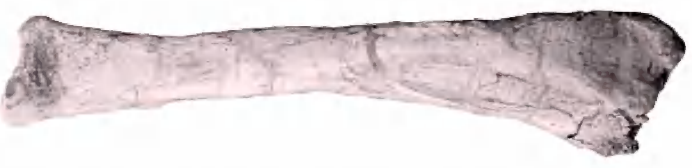

Fig. 3. Isotemnid antebrachia, ulnae A, B, and C; radii D, E, and F. A and D are of Anisotemnus distentus, AMNH 28906; B and $\mathrm{E}$ are of Thomashuxleya externa, AMNH 28653; $\mathrm{C}$ and $\mathrm{F}$ are of Pleurostylodon similis, AMNH 28904. All are shown as being from the right side, but the elements of Pleurostylodon (C and F) and the radius of Anisotemnus (D) are from the left, but digitally reversed to appear as right. Abbreviations are: ap, anconeal process; $\mathrm{cp}$, coronoid process; and ce, capitular eminence. The olecranon process of Pleurostylodon (C) is reconstructed. 


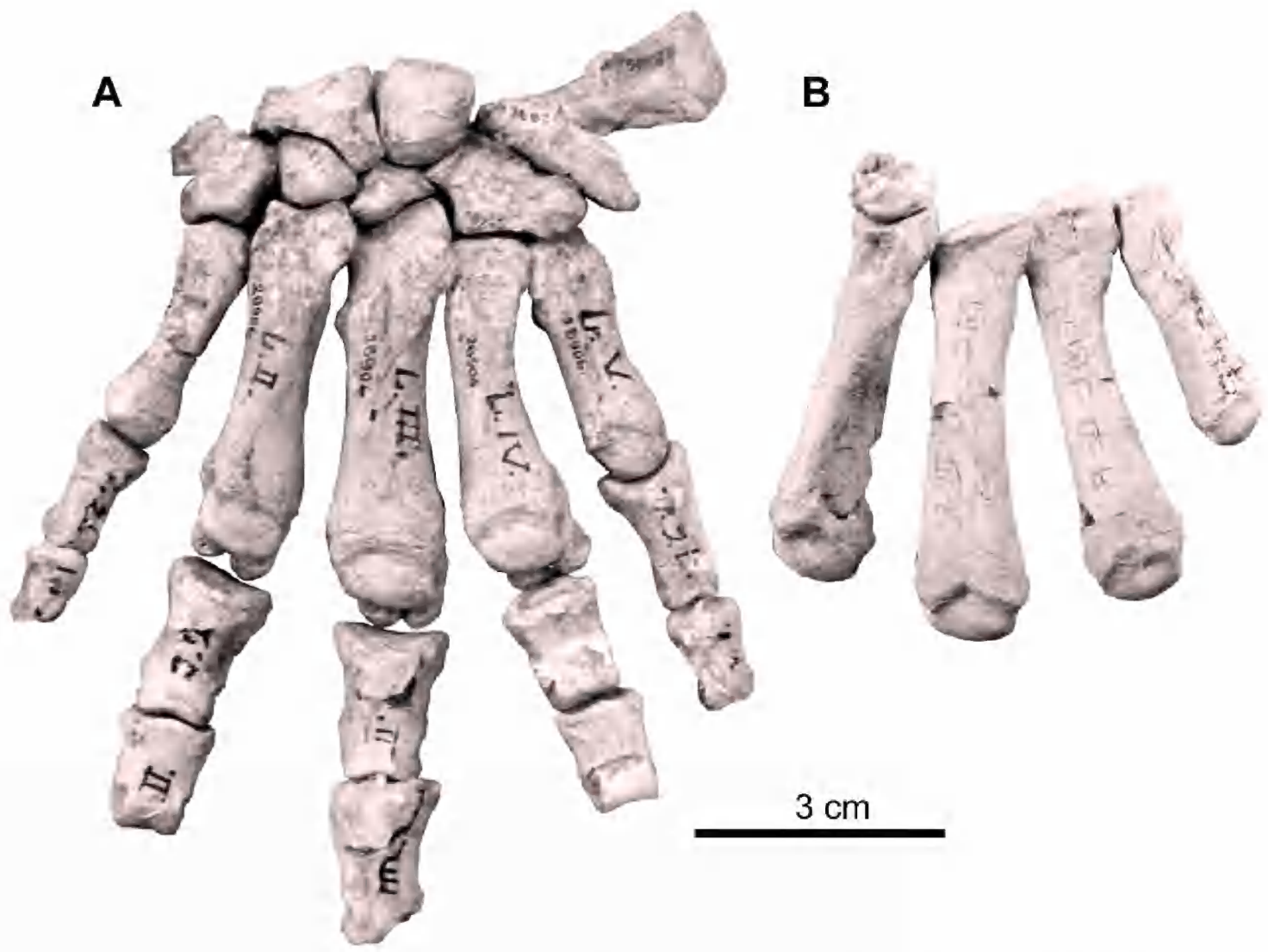

Fig. 4. Isotemnid hands: A, left manus of Anisotemnus distentus, AMNH 28906 and B, Pleurostylodon similis, AMNH 28904 shown as left, but reversed).

most morphologically primitive and earliest occurring hand known from a notoungulate (fig. 4A). The manus of Anisotemnus may be summarized as being pentadactyl, having a divergent, but not opposing, Mt I, and with the other metacarpals not compacted.

The manus of Anisotemnus is similar to that of the North American Paleocene ungulate Artocyon ferox $(=$ Claenodon ferox in Matthew, 1937) in that both are pentadactyl, have relatively short metacarpals, and have a similar arrangement of the carpals. In each, a single distal carpal supports a single metacarpal, except for the unciform, which articulates with both the Mt IV and V in the same plane, having no gross separation of the Mt IV or $\mathrm{V}$ facets of the unciform. None of the metacarpals is compacted. In terms of general size and form, the manus of Anisotemnus is a little larger and more robust than that of Arctocyon, which is more gracile, especially in terms of its elongated proximal phalanges, relative to the short, stout ones of Anisotemnus. Neither specimen of Anisotemnus has a separate centrale, but the process of the scaphoid that contacts the magnum likely represents the fusion of this element to the scaphoid, as occurs in some specimens of Arctocyon, but is a separate element in others (Matthew, 1937). The lunar in both taxa has a smooth articular surface for the radius that extends well over the dorsal face of the element, suggesting extreme and frequent wrist extension, as would occur in a plantigrade manus. Simpon (1936a) reported that the ungual phalanges of the Casamayoran Anisotemnus specimen were fissured; however, we have not found material to confirm this. Fragmentary terminal phalanges, however, do appear dorsoventrally compressed, unlike the transversely compressed, clawlike phalanges of Arctocyon (Matthew, 1937). As compared 

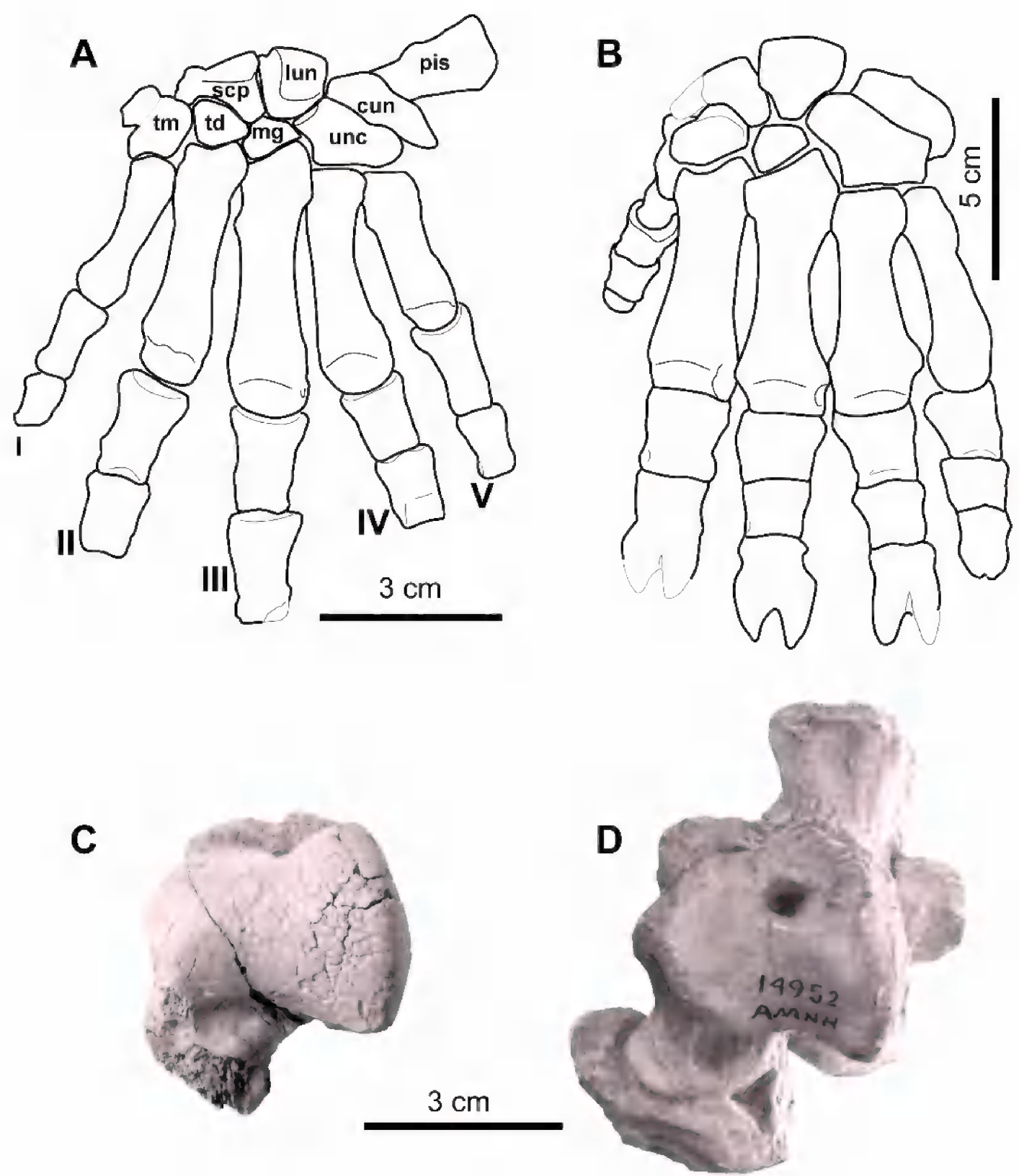

Fig. 5. Comparative anatomy of Vacan "subage" (Casamayoran SALMA) isotemnids with the Mustersan taxon Periphragnis harmeri. A, Manus of Anisotemnus distentus, AMNH 28906; B, manus of Periphragnis harmeri, AMNH 14952 (cast of Roth MLP specimen); C, left astragalus (dorsal view) of cf. Thomashuxleya externa, AMNH 142463; D, left astragalus, calcaneum, and navicular (dorsal view) of Periphragnis harmeri, AMNH 14952 (cast). Abbreviations of carpal elements: cun, cuneiform; lun, lunar; mg, magnum; pis, pisiform; scp, scaphoid; td, trapezoid; tm, trapezium; unc, unciform.

in more detail below, the manus of Anisotemnus is more similar to that of the Mustersan Periphragnis than to that of the Vacan Pleurostylodon similis (see fig. 5A, B).
Thomashuxleya externa Ameghino, 1901

Material: AMNH 28905 consists of many postcranial elements of a single individual that 
Simpson (1936a) referred to Thomashuxleya externa. It was found at Cañadón Vaca and was the primary source of postcranials for the skeletal reconstruction of Thomashuxleya (Simpson, 1938: fig. 1, 1967: fig. 35), which also included AMNH 28698 and 28447 for skull and jaw morphology. Postcranials of "contemporaneous, closely related animals" (Simpson, 1936: 10) from Cañadon Vaca were also used in the reconstruction. The "closely related animals" he referred to were AMNH 28904 and 28906, which we refer to Anisotemnus distentus (above) and Pleurostylodon similis (below), respectively.

We refer AMNH 28653 to $T$. externa as these associated elements are indistinguishable from homologous elements of AMNH 28905. This specimen is composed of postcranial elements only, including a partial right forelimb, which includes a distal humerus, complete radius, ulna lacking only the distal region, unciform, and $\mathrm{Mc} \mathrm{V}$.

Description: AMNH 28905 was associated with cranial remains "too extremely disintegrated to be worth restoration or even collecting, but permitted certain field identification as a species of Thomashuxleya" (Simpson, 1936: 1). Of the postcranial remains available from Cañadón Vaca, these are the largest; they are similar in size to the cranial and dental remains of Thomashuxleya externa, supporting referral of these remains to that taxon.

The humerus of Thomashuxleya is similar to that of Anisotemnus distentus in the form of its supinator crest, deep olecranon fossa, and presence of an entepicondylar foramen (which is not obvious in fig. $2 \mathrm{~B}$ as a result of postmortem damage). It differs from Anisotemnus in its slightly larger size, oblique rather than orthogonal orientation of the capitulum, and the orthogonal rather than oblique orientation of the trochlear groove. Also, whereas the medial flange is large in Anisotemnus distentus, the homologous feature in Thomashuxleya is much less developed (compare fig. 2A with fig. 2B). The trochlear groove as viewed from the posterior side also illustrates the orthogonal rather than oblique movement at the elbow joint. The posterior region of the trochlea is also broader and not as well defined by the trochlear crests, which are shallower in Thomashuxleya than in Anisotemnus.

The ulna of Thomashuxleya (fig. 3B) is more robust than that of Anisotemnus and is distinguished by the downward curvature of the olecranon process, lesser excavation of the lateral shaft, and its higher, pointed anconeal process (fig. 3). Also, whereas there is a slight bowing of the ulnar shafts of Anisotemnus and Pleurostylodon (below), such that in lateral view the shaft is ventrally convex, the reverse is true for Thomashuxleya, as its ulnar shaft is ventrally concave in lateral view (fig. $3 \mathrm{~B}$ ).

The radius of Thomashuxleya (fig. 3E) differs from that of Anisotemnus by way of the simple radial head, lacking the dorsointermediate groove and the capitular eminence seen in Anisotemnus. The distal ends of the Thomashuxleya radius specimens are dorsoventrally deeper than in Anisotemmus.

The unciform is distinct from that of Anisotemnus in its larger size and in the facets of Mc IV and V being at angles to one another, such that the $\mathrm{Mc} V$ is more divergent in Thomashuxleya than in Anisotemnus. The Mc $\mathrm{V}$ of Thomashuxleya has a more robust proximal articulation and has facets indicating contact with the Mc IV as well as with the unciform. The rest of the manus is damaged, but it is so perfectly reconstructed in the mount that any further description of it runs the risk of describing the handiwork of a museum technician rather than that of Nature.

cf. Thomashuxleya externa Ameghino, 1901

(possibly Anisotemnus distentus Ameghino, 1901)

Material: AMNH 142463 left astragalus, from Cañadón Vaca.

Description: The astragalus lacks any association with dental remains that might provide species-level identification. Its form is similar to that of material referred to Thomashuxleya rostrata by Ameghino (1904: fig. 24), although it is a little smaller and lacks the distinctive medial process observed in Ameghino's specimen. Based on its size, it may be tentatively referred to Thomashuxleya externa, but it is quite possibly an astragalus of Anisoteminus (which is otherwise currently unknown). 
The body of the astragalus (fig. 5C) is transversely broad and relatively short anteroposteriorly. The trochlea is shallow and asymmetric, with the medial border being short and rounded. The lateral trochlear ridge is a little higher than the medial border, and it forms a sharp angle between the lateral tibial articulation and the vertically oriented fibular facet. A superior astragalar foramen is present, but a plantar foramen is not observed. The superior astragalar foramen is flanked on the medial side by an extension of the medial trochlea, but the lateral part of the trochlea terminates sharply, leaving a groove from the foramen to the proximolateral border of the element. The ectal facet is damaged at the distal region, but clearly is much broader than the sustentacular facet. The neck is short and has a shallow tibial "stop" that runs obliquely on its dorsal surface. The astragalar head is missing.

This element differs from that referred to Thomashuxleya rostrata by Ameghino (1904: fig. 24) in its smaller size and in the absence of a conspicuous medial process. It is more similar to a Roth specimen of the Mustersan Periphragnis harmeri (Roth, 1899; AMNH 14952, cast of MLP specimen). AMNH 142463 and the astragalus of Periphragnis are of similar size, have asymmetric trochlear ridges and short necks (fig. 5C, D). The astragalus of Periphragnis differs in its deeper, more rounded trochlea, which forms a more perfect cylinder in lateral view in Periphragnis than that of Thomashuxleya. The Periphragnis astragalus also has a small, blunt medial process (lacking in the Cañadón Vaca specimen) and a larger astragalar foramen.

\section{Pleurostylodon Ameghino, 1897}

\section{Pleurostylodon similis Ameghino, 1901}

Material: AMNH 28904, partial skeleton containing right $\mathrm{M} 1$; left forelimb including humerus, ulna, radius, and Mc IV, right Mc II-V, right trapezoid; and both right and left femur and tibia, right navicular, and right $\mathrm{Mt}$ I. AMNH 28904 was found at Cañadón Vaca ("Vacan" "subage" of the Casamayoran) in 1931 and was included in Simpson's (1936a, 1967) descriptions of the skeleton of Thomashuxleya.
Description: AMNH 28904 is significantly smaller and morphologically distinct from the elements referred to Anisotemnus and Thomashuxleya above. The M1 associated with the postcranial elements is referable to Pleurostylodon; thus, we refer AMNH 28904 to $P$. similis based on the size and morphology of the M1 on the assumption that there is only one species of Pleurostylodon from Cañadón Vaca of that size range (Simpson, 1967).

Damage to AMNH 28904 precludes a comparative analysis of the proximal end of the humerus, but the shaft and distal end are reasonably complete (fig. $2 \mathrm{C}$ ). The deltopectoral crests are elevated, and the region of the lateral (deltoid insertion) side is greatly expanded. The medial crest (lesser tubercular) of the shaft is enlarged and expanded medially to a point greater than halfway down the shaft. The distal region is quite distinct from those referred to Anisotemnus and Thomashuxleya, being dorsoventrally compressed, whereas those of Anisotemnus and Thomashuxleya are deeper dorsoventrally (fig. 2). Some or much of this compression must have occurred after death, since the trochlea is too narrow to have articulated properly with the associated ulna. The medial epicondyle is relatively larger than in Anisotemnus and Thomashuxleya. Like Anisotemnus and Thomashuxleya, it has an entepicondylar foramen. The trochlea is shallow, and the medial trochlear flange is only slightly raised above the trochlear groove. The trochlea terminates posteriorly above the broad, shallow olecranon fossa. Solid bone fills the fossa, whereas this region was very thin or perforated in the olecranon fossae of Anisotemnus and Thomashuxleya.

The ulna (fig. 3C) is distinct from those in taxa described above (fig. 3A, B) in its smaller size and straighter olecranon, which lacks the medial curvature present in Anisotemnus and Thomashuxleya, as well as the downward curvature seen in Thomashuxleya. The coronoid process has the same relative height as in the other taxa, but the anconeal process is lower and has broader curvature. The excavation of the shaft is not as great as in Anisotemnus and is nearly lacking at the midshaft area, which is almost quadrate in cross section. The distal end does not taper, but rather becomes slightly enlarged in the dorso- 
ventral dimension. The distal region is too damaged to document any of its characteristics.

The proximal radius (fig. 3F) is similar to that of the Barrancan Pleurostylodon modicus (AMNH 28878) in having a capitular eminence, neither of which is as sharp and distinctive as that of Anisotemnus. The radius referred to $P$. similus is distinct, however, in that the proximal ulnar facet is conspicuously large and smooth and grades into a ridge connecting the articular circumference of the head to the bicipital tuberosity.

The manus (fig. 4B) is incomplete but includes $\mathrm{Mc}$ II-V and a trapezoid. One cannot conclusively say the hand was pentadactyl, since no Mc I was recovered, but an Mt I is preserved, suggesting a pentadactyl foot. The metacarpals are similar to those of Anisotemnus, but they are generally more gracile. Also, the magnum-Mc III joint appears to differ from that of Anisotemmus (and most notoungulates) since it lies on the same plane as the cuneiform-Mc IV joint, whereas the carpo-metacarpal joint of the third digit is oblique and more proximally positioned than that of digit IV.

Of foot elements, the navicular and Mt I are preserved in this specimen. The navicular is nearly identical to the one described below for the indeterminate isotemnid, except that it lacks the distinctive entocuneiform facet that forms the medial border of that element. The proximal portion of $\mathbf{M t ~} \mathbf{I}$ is larger, but it is otherwise identical to that of the small, indeterminate isotemnid described below.

\section{Indeterminate Isotemnid Taxon (Possibly Near $P$. similis)}

Material: AMNH 28690, left hindlimb bones including proximal femur, much of the tibia and fibula, tarsals (lacking only the distal portion of the calcaneum), Mt I, Mt II, and another distal metatarsus (Mt III?), Collected by G.G. Simpson near "Oficina del Diablo", Cañadón Vaca ("Vacan" "subage" of the Casamayoran); AMNH 142462, left calcaneum, also from Cañadón Vaca.

Note: AMNH 28690 has postcranial elements smaller than homologous elements of Pleurostylodon similis described above (e.g., the total length of the tibia in this indeterminate taxon is about $90 \%$ that of AMNH 28635 [table 1]). It may represent a small individual of $P$. similis or a different, but unknown, related species. It is probably too large and morphologically distinct to represent any of the notostylopids or oldfieldthomasiids from Cañadón Vaca. The morphologically distinctive (and likely apomorphic) Mt I is close in form to that of $P$. similis, suggesting a close (or conspecific) affinity.

Description: Only the proximal end of the femur was recovered. This is similar to AMNH 28635 except that it is smaller and the third trochanter is a little more distally placed. Its greater trochanter is just slightly higher than the head, which is well defined by the constriction behind it. The head is directed about $45^{\circ}$ from the long axis of the shaft. The lesser trochanter projects from the shaft, beginning about $1 \mathrm{~cm}$ below the head and continuing distally for about $2 \mathrm{~cm}$. On the lateral surface, the base of the third trochanter projects near the level where the lesser terminated; however, the body of the third trochanter itself is broken.

A nearly complete pes is preserved (fig. 6). Although Mt I and II are the only complete metatarsals preserved, the morphology is sufficient to confidently infer that the foot was pentadactyl and had serially arranged tarsals that would have been most often positioned in a plantigrade stance during life.

The astragalus is nearly identical to that described and figured by Ameghino (1904: fig. 29) and referred only to the Isotemnidae ("Isotemnidae indeterminado", p. 259). It differs from that referred to Pleurostylodon biconus ( $=$ P. modicus) by Ameghino (1904: fig. 30) in the relatively smaller neck and head and relatively larger body. The body of the AMNH 28690 astragalus has a shallow trochlea that is slightly asymmetric, with the lateral ridge being a little higher than the medial. The smooth articular surface of the trochlea extends over the medial surface, demarcating the articulation with the tibial malleolus. A conspicuous superior astragalar foramen is present at the mid-proximodorsal region of the trochlea. Although the foramen is distinct from the smooth articular surface of the trochlea, it is engulfed on either side by dorsal extensions of the articular region. The articular surface for the medial tibia extends beyond 
the foramen such that it grades into the medial ridge of the distinctive groove for the flexor hallucis longus. The lateral trochlear ridge terminates in a manner that leaves a gap between it and the lateral wall of the flexor groove. The superior astragalar foramen extends through the body, exiting within the proximal region of the astragalar sulcus (the deep groove of the plantar surface, between the sustentacular and ectal facets). The long axes of these calcaneal facets nearly parallel one another. The plane of the ectal facet has a somewhat oblique orientation, such that its surface can be clearly viewed from both plantar and lateral perspectives.

The neck of the astragalus is constricted behind the head, but it is not very long. On the dorsal surface of the neck lies an oblique ridge that serves as a tibial stop. The head is subspherical, but appears oval-shaped in distal view, with the lateral dimension being about $45 \%$ greater than the dorsoplantar.

The astragalus of AMNH 28690 is similar to that of the oldfieldthomasiid Colbertia magellanica from the late Paleocene of Itaboraí described by Cifelli (1983). It differs in its larger size, slightly more transversely convex trochlea, deeper and longer digital flexor groove, and blunter medial process. The region of the head of Colbertia that Cifelli (1983) identified as the facet for the collateral ligament does not function as such in this Vacan specimen. Instead, it articulates with the proximally extended medial process of the navicular (see fig. 6A). This process is likely a fused "tibiale" as seen at the medial head of the astragalus of Arctocyon ferox (= Claenodon corrugatus in the description of Matthew [1937]).

The distal region of the calcaneum of AMNH 28690 is missing, but most of the element is well preserved and indistinguishable from $\mathrm{AMNH}$ 142464. In general appearance the calcaneum is relatively long, having a distal border that is oblique in dorsal view, with the lateral side extending farther than the medial, which grades into a broad sustentaculum. The sustentacular facet is teardrop-shaped, the apex of which is directed toward and forms a sharp border with the cuboid facet. A groove on the plantar side of the sustentaculum indicates the passage of the tendon of the flexor hallucis longus. An oblique sulcus separates the susten- tacular facet from the ectal facet, the latter of which lies obliquely above a dorsal prominence rising above the tuber, midway along the proximodistal line. The ectal facet is convex, as it wraps around the lateral surface of the prominence. Neither specimen shows clear evidence of a fibular facet, but both have some abrasion where limited articulation may have occurred. The distal region of the fibula suggests a weak articulation with the calcaneum. Just proximal to the middorsal calcaneal prominence is an elongated fossa, which lies dorsal to a crest that grades into the broad peroneal shelf. A blunt peroneal process, defined by a tendonal groove, forms the distolateral border of the calcaneum. The cuboid facet is teardrop-shaped with its apex directed to the medial side such that it underlies the apex of the sustentacular facet, which lies at a near right angle to the cuboid facet.

The calcaneum is similar to that of the oldfieldthomasiid Colbertia (Cifelli, 1983). Differences include its larger size, the small or absent fibular facet (that of Colbertia is well defined, and covers both the distal and proximal sides of the prominence), and the peroneal shelf being larger, giving the distal astragalus a broader appearance.

The cuboid is unremarkable other than that its distal articular facet is much broader than those of the cuneiforms, being nearly twice the width of the ectocuneiform. This strongly suggests that it articulated with two metatarsals: Mt IV and V.

The navicular has a deep, circular concavity that serves as the socket of the ball-and-socket joint of the astragalonavicular joint. It has a well-developed medial process, which is most distinctive in having an elongated facet for the entocuneiform.

The entocuneiform is the largest and most remarkable of the three cuneiforms. Its anteroposterior dimension is nearly twice that of the ectocuneiform. Its medial surface articulates with both the mesocuneiform and the navicular. The facet for $\mathrm{Mt} \mathrm{I}$ is oblique to the metatarsal facets of the other cuneiforms and the cuboid, resulting in a diverging hallux. In medial oblique view this facet is concave, but it is somewhat convex in its other dimension. The tip of the distodorsal apex is broken and missing. 
TABLE 1

Measurements of Elements of the Appendicular Skeleton of Selected Isotemnids

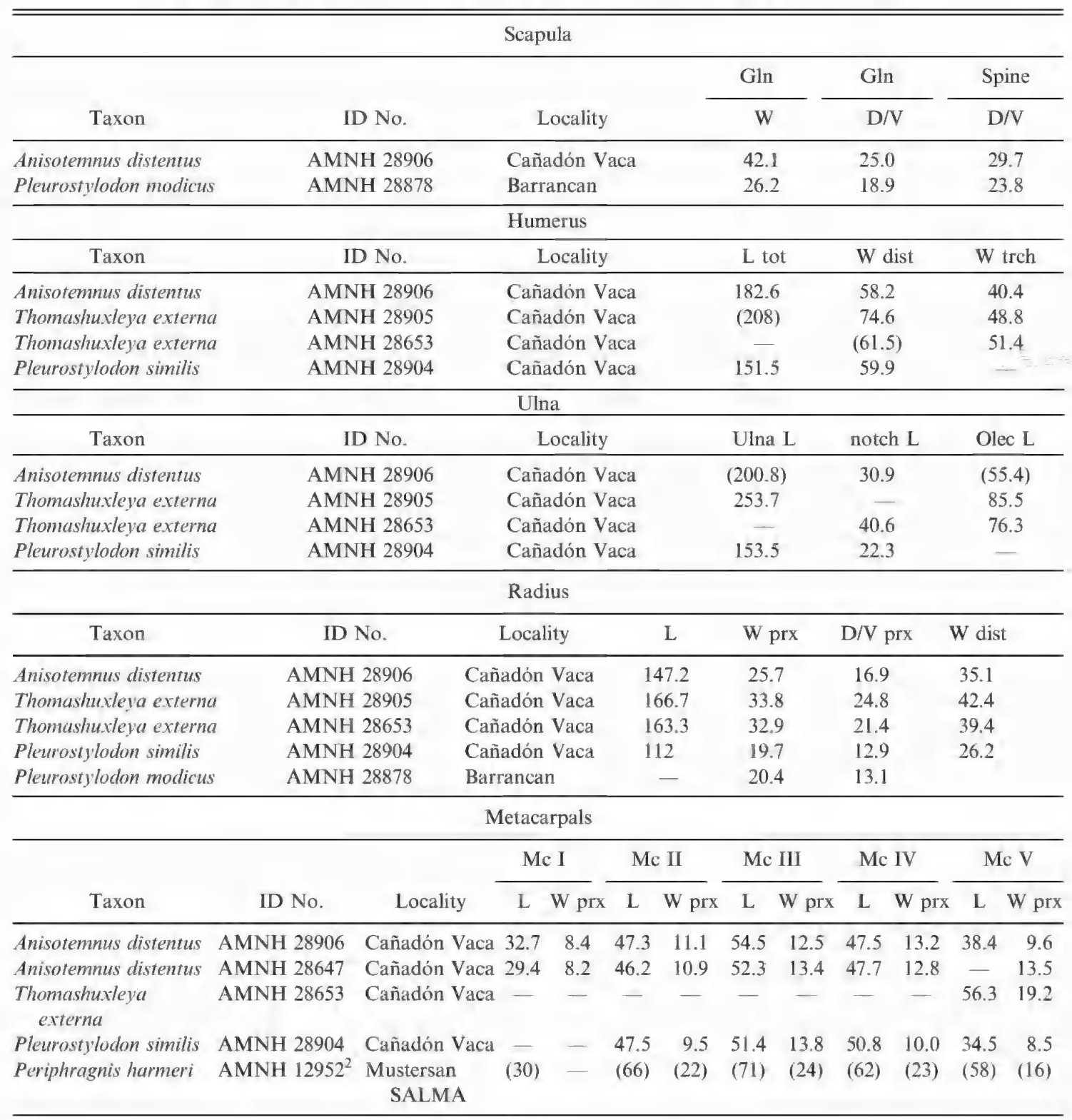

Femur

\begin{tabular}{|c|c|c|c|c|c|c|c|}
\hline & & & & Head & cond. & pat.trch & \\
\hline Taxon & ID No. & Locality & $\mathrm{L}$ total & W & W dist & $\mathrm{L}$ & W \\
\hline Pleurostylodon similis & AMNH 28904 & Cañadón Vaca & 151 & 23 & 36.8 & 36.5 & 18.6 \\
\hline Pleurostylodon similis & AMNH 28635 & Cañadón Vaca & 140 & 21.3 & 35.7 & 29.6 & 17.5 \\
\hline Isotemnidae indet. & AMNH 28690 & Cañadón Vaca & - & 18 & - & - & - \\
\hline Periphragnis harmeri & AMNH $12952^{2}$ & Mustersan SALMA & $(237)$ & $(31)$ & $(52)$ & (55) & (35) \\
\hline
\end{tabular}


TABLE 1

(Continued)

\begin{tabular}{|c|c|c|c|c|c|c|c|}
\hline \multicolumn{8}{|c|}{ Tibia } \\
\hline Taxon & ID No. & Locality & \multicolumn{2}{|c|}{ L tib } & W prx & D prx & W dst \\
\hline Pleurostylodon similis & AMNH 28635 & Cañadón Vaca & \multicolumn{2}{|c|}{120} & 26.2 & 35.1 & 21.9 \\
\hline Isotemnidae indet. & AMNH 28690 & Cañadón Vaca & \multicolumn{2}{|c|}{109} & 25.1 & 24.7 & 21.6 \\
\hline \multicolumn{8}{|c|}{ Astragalus } \\
\hline \multirow[b]{2}{*}{ Taxon } & \multirow[b]{2}{*}{ ID No. } & \multirow[b]{2}{*}{ Locality } & \multicolumn{5}{|c|}{ Head } \\
\hline & & & $\mathrm{L}$ tot & W trch & \multicolumn{2}{|c|}{$\mathrm{W} \max$} & $\mathrm{D} / \mathrm{V}$ \\
\hline cf. Thomashuxleya externa & AMNH 142463 & Cañadón Vaca & - & 35.8 & \multicolumn{2}{|c|}{40.7} & - \\
\hline Isotemnidae indet. & AMNH 142464 & Cañadón Vaca & 20.7 & 8.9 & \multicolumn{2}{|c|}{$(18.2)$} & 7.2 \\
\hline Isotemnidae indet. & AMNH 28690 & Cañadón Vaca & 22.0 & 11.3 & \multicolumn{2}{|c|}{20.5} & 7.6 \\
\hline \multicolumn{8}{|c|}{ Calcaneum } \\
\hline Taxon & ID No. & Locality & \multicolumn{2}{|r|}{$\mathrm{L}$ tot } & \multicolumn{2}{|c|}{ W tub } & W $\max$ \\
\hline Isotemnidae indet. & AMNH 142464 & Cañadón Vaca & \multirow{2}{*}{\multicolumn{2}{|c|}{$\begin{array}{c}38.1 \\
-\end{array}$}} & \multirow{2}{*}{\multicolumn{2}{|c|}{$\begin{array}{l}7.8 \\
7.4\end{array}$}} & \multirow{2}{*}{$\begin{array}{c}20.2 \\
(18.8)\end{array}$} \\
\hline Isotemnidae indet. & AMNH 28690 & Cañadón Vaca & & & & & \\
\hline \multicolumn{8}{|c|}{ Metatarsals } \\
\hline \multirow[b]{2}{*}{ Taxon } & \multirow[b]{2}{*}{ ID No. } & \multirow[b]{2}{*}{ Locality } & \multicolumn{3}{|c|}{ Mt I } & \multicolumn{2}{|c|}{ Mt II } \\
\hline & & & \multicolumn{2}{|r|}{$\mathrm{L}$} & W prx & $\mathrm{L}$ & W prx \\
\hline Isotemnidae indet. & AMNH 28690 & Cañadón Vaca & & 22.6 & 7.7 & 32.4 & 4.6 \\
\hline Pleurostylodon similis & AMNH 28904 & Cañadón Vaca & & - & 9.5 & & \\
\hline
\end{tabular}

${ }^{1}$ Measurements are given in millimeters. Estimated values from damaged specimens or casts are in parentheses. Measurements of the various elements are as follows: total length of the humerus is measured from the head (not including the greater tubercle) to the capitulum (not including any distal processes); distal width of the humerus includes a greatest width (W dist) and the transverse dimension of the ulnar articulation, including the trochlea and capitulum (W troch); the length of the trochlear notch of the ulna is measured from the coronoid process to the anconeal process; and the length of the olcecranon is measured from its tip to a point midway between the coronoid process and the anconeal process.

Abbreviations used in the table are as follows: Ant/Pst, anteroposterior; cond, condyle; D/V, dorsoventral; dist, distal; Gln, glenoid; L, length, the proximodistal dimension; Mc, metacarpal; Mt, metatarsal; Olec, olecranon; pat, patella; trch, trochlea (spool-shaped feature of humerus, patellar groove, or astragalus); tub, tuber of calcaneum; W, width, the transverse dimension.

${ }^{2}$ AMNH 12952 represents casts of a Museo de La Plata specimen collected by Santiago Roth. Measures are taken from the casts and are given as estimates.

Mt $\mathrm{I}$ is fairly short, but its proximal surface shows that it was not a vestigial element. It has an elongated articular surface, convex in the anteroposterior dimension and transversely concave, with the relative degrees of these curvatures clearly indicating that most of the action at the tarsometatarsal joint was in the parasagittal plane.

The proximal Mt II has the typically grooved proximal facet for the mesocuneiform. Its articulation with the ectocuneiform appears on a small lateral process of the Mt II that physically separated the shaft of Mt II from Mt III (fig. 6A), but it does not overlap any portion of the ectocuneiform.

None of the remaining metacarpals was recovered, except for a distal region of one of these (either Mt III or IV). However, the large size of the distal articular surface of the cuboid indicates that it must have supported more than a single metatarsal, indicating the probable presence of an $\mathrm{Mt} \mathrm{V}$, and therefore the pentadactyl state of the foot.

Compared to the pes of Arctocyon, that of the indeterminate isotemnid is smaller, has relatively and absolutely shorter and thinner 

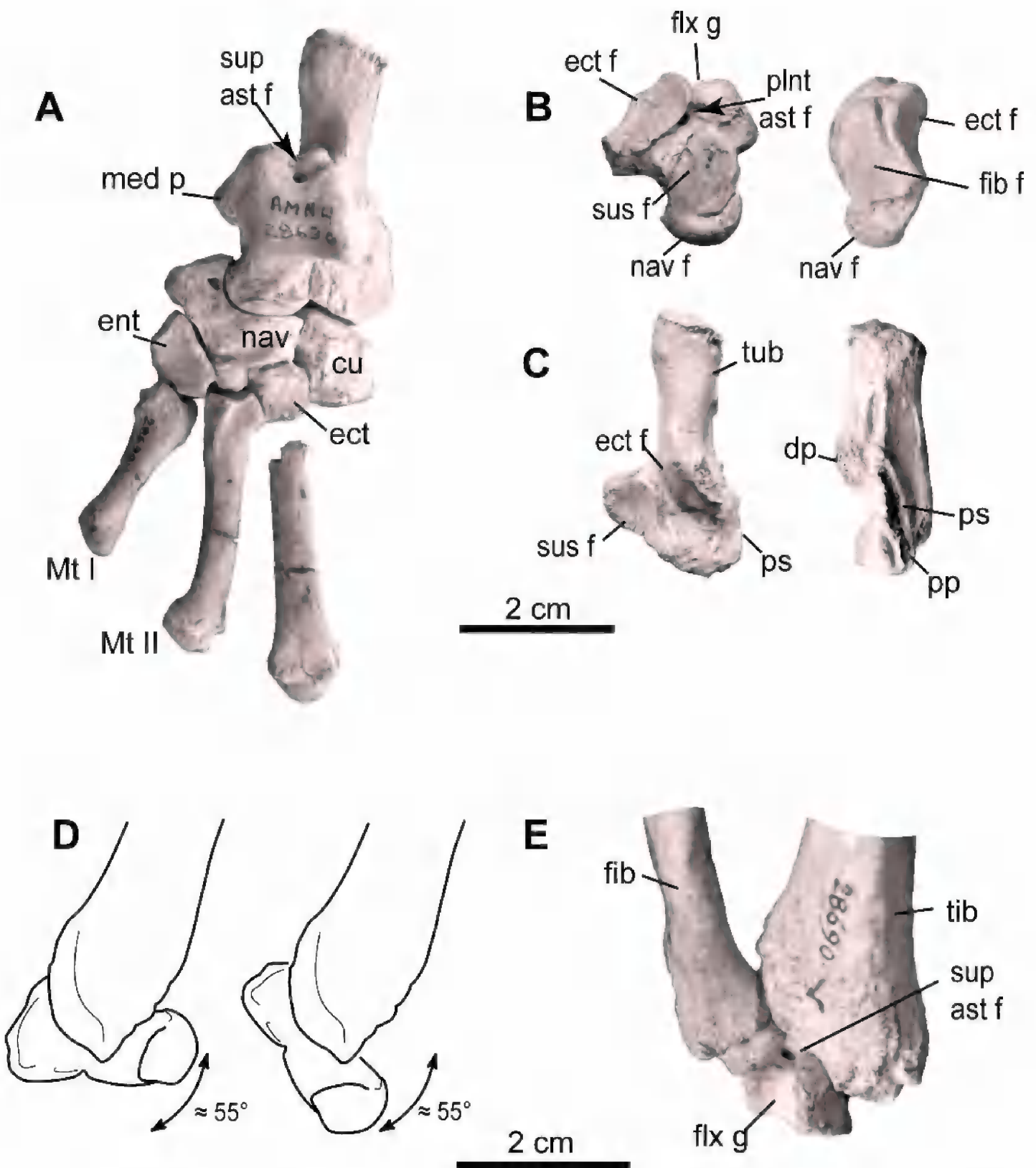

Fig. 6. Isotemnid foot. AMNH 28690. A, Dorsal view of pes; B, astragalus in plantar view (left) and lateral view (right); $\mathbf{C}$, calcaneum in dorsal view (left) and lateral view (right); $\mathbf{D}$, line drawing illustrating maximum dorsiflexion of the upper ankle joint (left) and maximum plantarflexion (right); E, posterior view of upper ankle joint at maximum plantarflexion, showing the exposed superior astragalar foramen and groove for the tendon of the flexor hallucis longus. Abbreviations: cu, cuboid; dp, dorsal; ect $\mathrm{f}$, ectal facet; ent, entocuneiform; fib, fibula; fib f, fibular facet; flx g, groove for the tendon of the flexor hallucis longus; med p, medial process; nav, navicular; nav f, navicular facet; plnt ast f, plantar astragalar foramen; pp, peroneal process; ps, peroneal shelf; sup ast $\mathrm{f}$, superior astragalar foramen; tib, tibia. (The upper scale bar applies to $\mathrm{A}, \mathrm{B}$, and $\mathrm{C}$, the lower bar to $\mathrm{D}$ and $\mathrm{E}$.) 
metatarsals, a smaller mesocuneiform, a larger entocuneiform, and no separate tibiale, but it has an enlarged process of the navicular that may represent fusion of a tibiale to the navicular. The astragalus of the isotemnid is less cylindrical about the trochlea (flatter) and has a distinctive medial process lacking in Arctocyon, an oblique crest ("tibial stop") on the dorsal side of the neck, a more distinctive flexor groove, and a medial groove from the superior astragalar foramen to the proximomedial surface of the element. The calcaneum of the indeterminate isotemnid is narrower (mediolaterally compressed) and has a less robust peroneal process and a more oblique articulation with the cuboid.

\section{DISCUSSION}

\section{Postcranial Diversity in Casamayoran (VACAN) ISOTEMNIDS}

The dentitions of isotemnids of various Casamayoran localities are so similar that Simpson (1967) briefly considered the possibility that they all represented a single species. Regardless of the degree of dental similarity or distinctiveness, the variation "of not more than generic value" (Simpson, 1936a: 2) in their postcranial skeletons is noteworthy. Marked differences in the forelimb, the best known part of the locomotor system of Casamayoran isotemnids, suggest functional as well as taxonomic differences.

The elbow joints of Anisotemnus and Thomashuxleya suggest functionally significant differences between these two larger isotemnids. Thomashuxleya appears to have had a more erect stance than did Anisotemnus. The erect stance in Thomashuxleya is inferred from the downward curvature of the olecranon and the bowing of the ulna where the ventral side of the shaft is concave (in lateral view), whereas it is somewhat convex in Anisotemnus and Pleurostylodon (fig. 3). The form in Thomashuxleya is more typical of that seen in other ungulates and in terrestrial and cursorial Carnivora (Van Valkenburgh, 1987). As a biomechanical principle, force acting upon a lever will have maximum effect at $90^{\circ}\left(\sin 90^{\circ}=1\right)$. Thus, in order to have the greatest potential force to initiate elbow extension, the olecranon should be oriented perpendicularly to the extensor muscles (e.g., triceps). Invariably, the olecranon is curved downward, relative to the shaft, in mammals having very erect stances (e.g., bovids, equids). The upward olecranon orientation and shaft of the ulna (ventrally convex in lateral view) is uncommon (or unknown) in extant ungulates but occurs in some arboreal carnivorans (e.g., the binturong, Arctictis; see O'Leary and Rose, 1995).

In contrast to Thomashuxleya, the ulnar shafts of Anisotemnus and Pleurostylodon are ventrally convex in lateral view, with the olecranon being slightly curved such that the terminal end is directed dorsally (upwardly curved olecranon). This suggests that these animals had a less erect posture, or more of a crouching stance, than did Thomashuxleya. The trochlea of the humerus of Anisotemnus is more obliquely oriented, which is also suggestive of a crouching stance and plantigrade manus (Ginsburg, 1961).

The manus of Anisotemnus differs little from that of Paleocene carnivorans and "condylarths". It probably frequently supported the animal in a forelimb plantigrade position, as evident from the radial facet of the lunar covering much of its dorsal face. The manus of Anisotemnus is larger and more robust than the partial manus of Pleurostylodon (with its midshaft metacarpal diameters being relatively and absolutely greater). Its proximal Mc III overlies the proximal Mc IV, which originates more distally than that of Pleurostylodon. In metacarpal arrangement the manus of Anisotemnus is more similar to the Roth specimen of Mustersan Periphragnis (see fig. 5 and Simpson, 1967) than to Pleurostylodon. If Roth correctly reconstructed the position of the trapezium (and we that of Anisotemnus), then the pollex of Periphragnis diverges more than that of Anisotemnus.

The astragalus of cf. Thomashuxleya has a fairly flat and shallow trochlea that retains the astragalar foramen, although this foramen has a smaller diameter than that in the small, indeterminate notoungulate. Its trochlea is so flat and shallow, however, that little rotation could have occurred at the upper ankle joint, even less than that proposed for the pes of the small notoungulate (below). The form of the astragalus indicates that the tibia habitually rested at a near right angle to the long axis of 
the astragalus, as occurs in plantigrade mammals (Carrano, 1997).

The similarity of the astragalus in $\mathrm{cf}$. Thomashoxleya to that of Periphragnis harmeri is not surprising given their dental similarities, the latter of which stimulated hypotheses of there being a close phylogenetic relationship between these Casamayoran and Mustersan taxa (Ameghino. 1906: Simpson, 1967). The astragalus of Periphragnis is indistinguishable from that of the Mustersan astragalus referred to "Proasmodeus armatus" by Ameghino (1904). This is consistent with the synonymy proposed by Simpson (1936b, 1967), which was based on his study of their dentitions. He regarded Proasmodeus armatus to be a junior synonym of Periphragnis harmeri. It is also noteworthy that the calcaneum of $P$. harmeri has a well-developed fibular facet that is somewhat laterally placed and has a steep distal face. This distinctive form is similar to that seen in homalodotheriids (Scott, 1912b) and is compatible with Bond's recent informal placement of Periphragnis within the Homalodotheriidae (noted by Flynn et al., 2003) and with Ameghino's assertion of a close relationship of Periphragnis (his "Proasmodeus") with the Deseadan homalodotheriid Asmodeus (Ameghino, 1906).

The pes of the small, indeterminate isotemnid (AMNH 28690) lacks characters typically found in cursorial, digitigrade mammals. It is pentadactyl, has divergent and short metatarsals, a short, shallow trochlear groove of the astragalus, and it retains a well-developed astragalar canal, all of which are characteristic of mammals with plantigrade posture (Ginsburg, 1961; Wang, 1993; Carrano, 1997).

The function of the astragalar canal (manifest by superior and/or plantar astragalar foramina) is unknown and its significance has long been disputed (Osborn, 1889; Ameghino, 1904; Schaffer, 1947; Szalay. 1966). Known mostly from Paleocene and Eocene "condylarths" (e.g., Arctocyon [arctocyonid] and Chocroclaenus [hyopsodontid]; see Schaffer, 1947), "creodonts" (e.g., Patriofelis; Wortman, 1894), and carnivorans (e.g., Vulpavus; Wang, 1993), its function cannot be determined directly, but its significance as an indicator of foot posture had been considered in some detail.
Osborn (1889) suggested that the upper ankle joint in Puercan (early Paleocene, North America) genera had limited anteroposterior mobility, due to the short tibial articulation of the astragalus and by motion blockage that would be caused by tissue leaving the astragalar foramen, which he thought was probably a muscle. In contrast, Schaeffer (1947) doubted the significance of these points. He noted that the extant aardvark (Orycteropus) has an astragalar foramen, and thin sections of its contents revealed only connective tissue: no blood vessels, nervous tissue, or muscle were present that would have been harmed by, or blocked, foot extension. Indeed, he pointed out that Orycteropus extends its foot such that the tibia covered the superior astragalar foramen.

Szalay (1966) argued that the absence of a particular function of this foramen in Orycteropus did not mean absence of function in extinct taxa. The foramen in the aardvark astragalus could be a vestige of the condition in its ancestors, in which the foramen passed additional tissues that would have impeded the full extension of the foot. In a similar fashion. Schaeffer (1947) noted that the ontogeny of the foramen in the aardvark was unknown (it appears to be unknown still) and could have housed something of functional significance early in ontogeny. Ameghino (1904) documented numerous examples of features of astragali that appeared to protect the contents of the astragalar canal from shearing damage from movement of the tibia, or compressive or abrasive damage from action of the tendon of the flexor hallucis longus. Such traits included a "bridge" ("puente" in Spanish, a small ridge between the flexor groove and the superior astragalar foramen) and a groove that developed within the tibial facet, seemingly to allow safe passage posteriorly of the contents of the astragalar canal. The latter is seen in the specimen of the small, indeterminate isotemnid, in which the superior astragalar foramen is engulfed on three sides, with the resultant groove forming a passage to the proximolateral border that would remain open throughout the full range of motion of the upper ankle bones.

Without commenting on these controversies, Wang (1993) used his recent cladistic 
phylogeny to document the pattern of transition from plantigrady to digitigrady in canids, one of the few such studies of locomotor transformation within the basal diversification of a mammalian group. The relevance of this work, however, extends beyond carnivorans because similar evolutionary transitions have occurred in a variety of other taxa, including artiodactyls (Schaeffer, 1947), phenecodonts/ perissodactyls (Radinsky, 1966), litopterns (Cifelli, 1983), as well as notoungulates.

In particular, Wang (1993) documented the transition of generalized, or even arboreal, astragalus of some "miacoids" (basal, early Cenozoic carnivoramorphans) through to the derived, cursorial form found in canine canids. The middle Eocene "miacoid" Vulpavus served as the outgroup for the Canidae (i.e., the clade of hesperocyonines [borophagines, canines]). and provides a model for the ancestral condition of the canid foot. In particular, the astragalus of the "miacoid" Vulpavus has a short, shallow trochlea, a welldeveloped, separate flexor groove (= "plantar tendon groove"), and a superior astragalar foramen that appears in a fossa that forms a discontinuity between the trochlea and flexor groove. Wang argued that the ankle extension required for digitigrady was not possible due to the short, shallow trochlea. The foot of canine canids, however, represents the most derived form in terms of terrestrial adaptations (Wang, 1993). The astragalus of nearly all known canines has a well-developed trochlea that, by way of the loss of the astragalar foramen and associated fossa, coopts the flexor groove into the trochlea, thus extending the potential tibial articular surface over to the extreme proximal surface and potentially even the proximoplantar region of the astragalar body.

The loss of the astragalar foramen and its associated fossa is significant for two reasons: (1) whatever had passed through the astragalar canal was no longer there to physically block or be damaged by the shearing that would have occurred with movement of the tibia over the dorsocaudal region of the astragalus, and (2) the union of the flexor groove with the astragalar trochlea fortuitously provided an extension of the trochlea for tibial articulation, thus greatly increasing the angle of arc for the tibioastragalar rotation. Greater rotation of the upper ankle joint allowed increased plantarflexion of the foot during locomotion, which increases stride length and thus velocity (assuming constant stride rate). This process is best documented in canids: however, the same mechanical principles apply to other groups in which the superior astragalar foramen and its associated fossa is lost and replaced with articular surface for rotation with the tibia.

Like the astragalus of the "miacoid" carnivoramorphan Vulparus, noted by Wang (1993), that of the small, indeterminate Vacan isotemnid notoungulate described above has a short, shallow trochlea separated from the flexor groove by a fossa that contains a superior astragalar foramen. It is a single complete canal (one can easily see through it), unlike that of some other early placental mammal taxa (e.g., the Paleocene lepticid Prodiacodon; Szalay, 1966), in which the superior astragalar foramen is distinct and separated by a bony partition from the plantar astragalar foramen. The limited rotation of the upper ankle joint of the Vacan isotemnid Pleurostylodon is indicated not just by the presence of the canal, but also by observations made when manually rotating the astragalus within/across the articular surfaces of the crus. Maximum dorsiflexion (or hyperflexion, since we do not include the effects of the soft tissues) occurs where the tibial process meets the tibial stop (the oblique ridge of the astragalar neck) and the neck. (The distal tip of the tibial process is broken in AMNH 28690, but the position of maximum dorsiflexion is still unambiguous, as the neck itself serves as a stop.) Maximum plantarflexion (foot extension) occurs when the distal articular surfaces of the crus cover the proximal articular surfaces of the astragalus, Although these extend beyond and mostly engulf the superior astragalar foramen, the oblique form of the tibia still allows exposure of the superior astragalar foramen, even at maximum plantarflexion (fig. $6 \mathrm{D}, \mathrm{E}$ ). In the upper ankle joint the movement of the astragalus from maximum dorsiflexion to maximum plantarflexion forms an arc of about $55^{\circ}$. This angle likely was somewhat less in life, since this estimate does not include any constraining effects of soft tissues. 
As far as is known. the Vacan isotemnids lack the deep, elongated trochlea noted by Wang (1993) for borophagine and canine canids, as do most post-Eocene notoungulates (discussed below). Anisotemnus and Pleurostylodon have forelimbs that suggest a crouching stance, and the manus of Anisotemms was probably plantigrade. Thus, these two taxa appear to lack significant adaptations for rapid terrestrial locomotion. The forelimb of Thomashuxleva, however, does hint at an erect stance. but if observations of the astragalus (referred by us to that taxon) or of any astragali referred to Thomashuxleya by Ameghino are correct, then the hindlimb stance of Thomashuxleya was probably plantigrade. Thus, it appears that Vacan isotemnids lack significant adaptations for running.

\section{Paleoecology}

The dominance of herbivores with lowcrowned teeth in Eocene and older faunas of South America, contrasted with the dominance of high-crowned forms in the Oligocene and younger faunas, is well documented (Patterson and Pascual, 1972; Pascual and OrlizJaureguizar, 1990; Kay et al., 1999; Flynn et al., 2003). The dominance of taxa with lowcrowned teeth is generally regarded as indicating fairly closed habitats in the Eocene. contrasted with generally more open environments of the Oligocene (Tinguirirican and Deseadan SALMAs). These may have included some of the world's first grasslands (Flynn et al., 2003), an environmental stimulus for the evolution of hypsodonty (Janis, 1995). Additionally, the comparative faunal structure analysis of Croft (2001) suggests that habitats that produced fossils of the Barrancan "subage" of the Casamayoran were heavily forested, with warm temperatures and plentiful rainfall. Indeed, in terms of species richness and relative body sizes, the Barrancan fauna suggests temperature and rainfall even higher than that which occurs in modern tropical forests.

Like many Eocene faunas around the world, the Casamayoran has been known for its diversity of anatomically primitive, "archaic" ungulates. Thomashuxleya. which Simpson (1935) characterized as being just a little larger than a sheep, was the largest mammal in South America at that time. The dentitions of Thomashuxleya and other notoungulates were relatively unspecialized and brachydont. Our review of the appendicular skeleton suggests that, although some variability occurred among isotemnid notoungulates, their foot posture and locomotion also were relatively unspecialized.

Most ungulates in Casamayoran faunas retained the astragalar foramen. Of the 23 different Casamayoran astragali discussed and figured by Ameghino (1904), 15 (65\%) had well-developed foramina; another 5 (22\%) had a reduced, vestigial foramen, and only 3 $(13 \%)$ lacked any trace of the foramen. It is noteworthy that the proportion of taxa having the foramen is greater than those reported for older faunas from the late Paleocene of Itaborai, Brazil. Of the 13 morphotypes or groups of astragali of endemic South American ungulates documented from Itaborai by Bergquist (1996), 10 had an astragalar canal. It was completely absent in three morphotypes, all of which were of litopterns (Cifelli, 1983). The foramen also is known to be absent in the astragalus of the xenungulate Carodria (Cifelli, 1983). Thus, $4(29 \%)$ of 14 Itaborai ungulate morphotypes lacked the astragalar foramen. Those possessing the foramen included didolodontids, astrapotheres, and notoungulates (Cifelli, 1983; Bergqvist, 1996).

Whereas taxa having astragalar foramina dominated Paleocene and Eocene faunas, they are rare in Oligocene or younger faunas of South America. Of the 11 known endemic ungulate taxa with associated astragali from Salla, Bolivia (Deseadan SALMA, late Oligocene), none has an astragalar foramen (Shockey and Anaya, in press), although a remnant of the fossa separating the trochlca from the flexor groove is present in most specimens of Trachytherus. Of taxa not represented at Salla, but known from other South American Deseadan localities, the homalodotheriid Asmodeus (Ameghino, 1904: fig. 25) has a well-developed astragalar foramen. and the astrapothere Parastrapotherium of Patagonia typically has a vestigial foramen. Additional Deseadan taxa known to lack the astragalar foramen include Rhynchippus pumilus and Scarrittia canquelensis (Chaffee. 1952). 
Moqueguahippus glycisma (Shockey et al., 2006), Prosotherium garzoni, Protherosodon coniferus, and Coniopternium andinum (Loomis, 1914, although $C$. andinum is given as Notodiaphorus by Loomis). Thus, of 19 Deseadan native ungulates for which the astragalus is known, $17(89 \%)$ have the modified upper ankle in which the astragalar foramen is lost. It is partially retained in one Deseadan taxon and conspicuous in another. Of 13 native ungulates of Santacrucian SALMA assemblages, $11(85 \%)$ have the lost the astragalar foramen, while only the homalodotheriid and astrapothere have the foramen (Sinclair, 1909; Scott, 1912a, 1912b).

There is little doubt that a plantigrade foot stance is the primitive condition for mammals (Wang, 1993). Also, the ubiquity of the astragalar canal in basal "condylarths", creodonts, and carnivoramorphans, as well as its documented loss in artiodactyls (Schaeffer, 1947), phenecodonts/perissodactyls (Radinsky, 1966), litopterns (Cifelli, 1983), and carnivores (Wang, 1993), indicates that its absence is convergently apomorphic in each of these groups. Its loss results in the lengthening of the tibial articulation, which allows greater ankle extension, a requirement for a digitigrade stance (Wang, 1993; Carrano, 1997).

We thus use the percentage of ungulate taxa lacking the astragalar foramen as an "ankle index" to estimate the proportion of the ungulate fauna having mobile upper ankle joints. This greater plantarflexion of the ankle results in greater stride length and thus velocity. Figure 7 indicates that mobile ankles were much less common than mobile upper ankle joints across the major ungulate clades in Paleocene and Eocene ungulate faunas of South America. However, proportions change markedly by the Oligocene, as ungulate taxa with mobile ankles dominate late Oligocene and younger faunas. Sample sizes are too low (or nonexistent) for Mustersan (late Eocene) and Tinguirircan (early Oligocene) SALMAs to estimate the rate at which the relative abundances of mobile ankle joints increased from the Eocene to Oligocene, obscuring whether the evolutionary changes in the foot occurred with the same rapidity as the origin of hypsodonty near the Eocene-Oligocene boundary (Flynn et al., 2003).

\section{CONCLUSIONS}

A moderate degree of morphological diversity of the postcranial skeleton is observed among Vacan (Casamayoran SALMA) isotemnid notoungulates. The largest bodied, Thomashuxleya, appears to have had a relatively erect forelimb, whereas Anisotemnus and Pleurostylodon each had a crouching stance, which, at least in Anisotemnus and probably in Pleurostylodon, included a habitually plantigrade posture of the hand. Although Thomashuxleya may have been habitually digitigrade in its forelimb posture, all known large astragali from the Casamayoran (which might pertain to Thomashuxleya) have a form that would have prevented the foot from extending sufficiently to support a digitigrade stance, thus suggesting either a plantigrade or semi-digitigrade posture in the hindlimb of Thomashuxleya. Thomashuxleya is dentally similar to the Mustersan taxon Periphragnis, and this analysis indicates that the astragali of these taxa are also similar (fig. 5). The calcaneum of Periphragnis has a fibular facet similar to that of homalodotheriids, suggesting a potential synapomorphy uniting Periphragnis with taxa generally regarded as being homalodotheriids (e.g., Asmodeus, Homalodotherium).

The foot of the small, indeterminate isotemnid differs little from that of basal ungulates ("condylarths"), carnivorans, and creodonts. The most distinctive, and reliably observed, derived characters of this pes and the tarsi of Paleocene-Eocene notoungulates generally are the oblique, dorsal crest of the astragalar neck (the "tibial stop") and the medial process from the astragalar body (the process is absent and the tibial stop is transverse in later-diverging Toxodontia and interatheriid notoungulates [Shockey and Anaya, in press]). Otherwise, the foot of early notoungulates is so little modified from the form typically observed in early ferungulates (and many other early eutherians) that it may be readily inferred that notoungulates evolved from a fully plantigrade, pentadactyl ancestor.

Although cursorial or subcursorial adaptations appear to have been rare among Eocene notoungulates, by the late Oligocene Deseadan SALMA, mobile upper ankle joints (and in many cases digitigrade foot posture) were the rule rather than the exception. This 


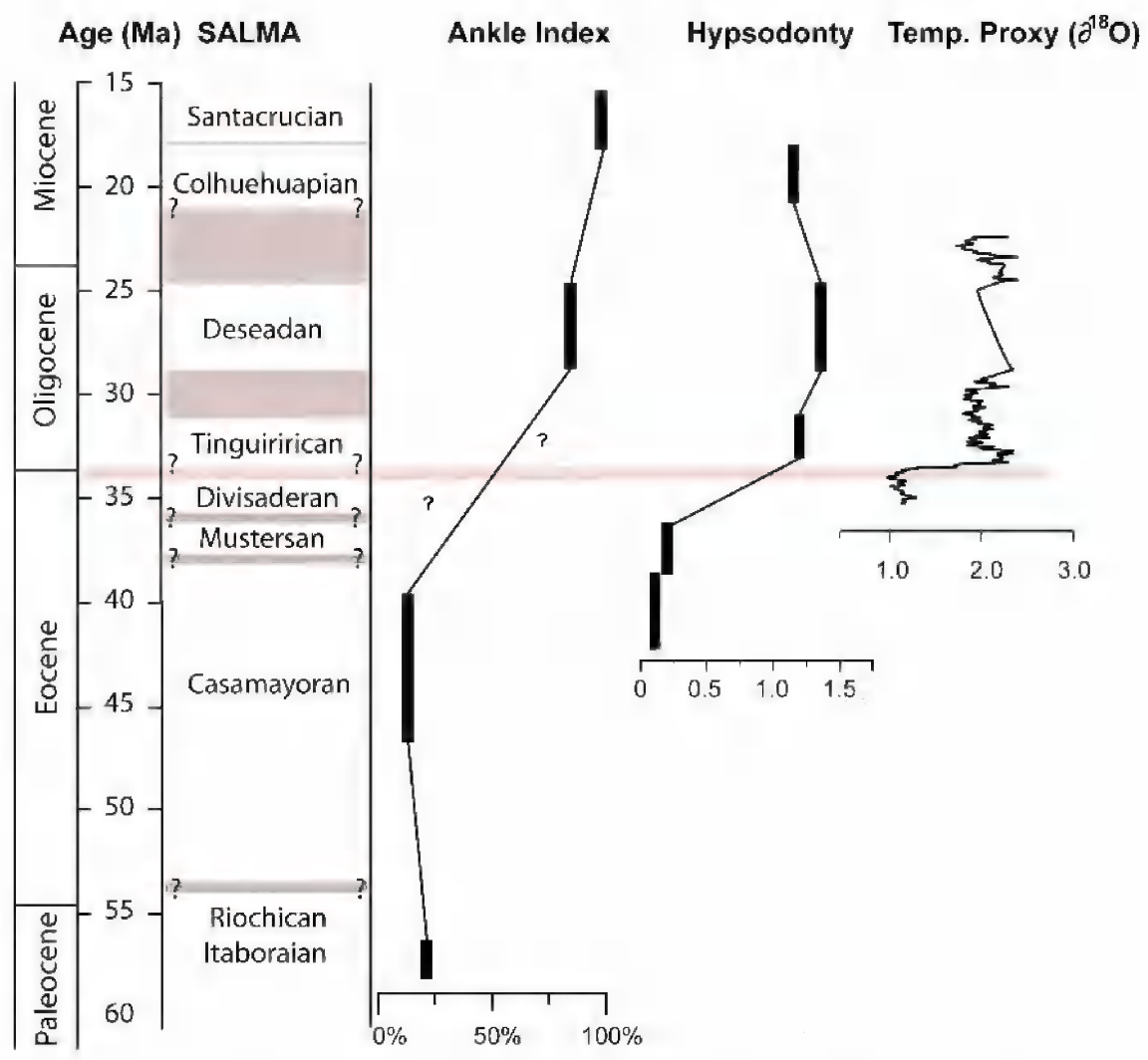

Fig. 7. Changes in foot structure in South American ungulates over time. The ankle index indicates the percentage of the ungulate taxa in a fauna that lacks an astragalar canal (i.e., superior astragalar foramen absent). This absence, and associated increase in the tibioastragalar articulation, is used as a proxy for the proportion of the ungulate fauna having a subcursorial to cursorial foot. The percentage having the modified form is compared to the mean ungulate hypsodonty, and changes in the proxy of global temperature $\left(\partial^{18} \mathrm{O}\right)$. Time scale, mean hypsodonty index, and temperature proxy are modified from Flynn et al. (2003).

indicates that just as there were profound evolutionary changes in the dentitions of notoungulates across the Eocene-Oligocene transition, there were also fundamental evolutionary changes in their foot structure, posture, and locomotion, possibly correlated with paleoecological shifts to the more open habitats typical of the mid-late Cenozoic across much of South America.

\section{ACKNOWLEDGMENTS}

This research was facilitated by a grant from the National Science Foundation (DEB 0513476 to J.J.F) and research scientist support for B.J.S. from the Frick Fund of the AMNH Division of Paleontology. We thank A. Wyss, D.A. Croft, and Jin Meng for their comments regarding the initial version of this paper. Croft suggested the use "Ankle Index" to replace our clumsy and cumbersome descriptor of the index for upper ankle joint mobility. Notes left in the AMNH collection some 20 years ago by R.L. Cifelli facilitated the exploratory part of this study. We are grateful for these notes and we salute Cifelli's pioneering work on craniodental and postcranial anatomy, and cladistic analysis of the phylogeny of notoungulates.

\section{REFERENCES}

Ameghino, F. 1895. Sur les oiseaux fossils de Patagonie et la faune mammalogique des 
couches à Pyrotherium. II. Première contribution à la connaissance de la faune mammalogique des couches à Pyrotherium. Boletín del Instituto Geográfico Argentino 15: 603-660.

Ameghino, F. 1897. Les Mammifères crétacés de l'Argentine: deuxième contribution à la connaissance de la faune mammalogique des couches à Pyrotherium. Boletín del Instituto Geográfico Argentino 18: 406-521.

Ameghino, F. 1901. Notices préliminaries sur des ongulés nouveaux des terrains Crétacés de Patagonie. Boletin de la Academia Nacional de Ciencias de Córdoba 16: 1-349.

Ameghino, F. 1902. Notices préliminaries sur des ongulés nouveaux des terrains Crétacés de Patagonie. Boletin de la Academia Nacional de Ciencias de Córdoba 17: 5-70.

Ameghino, F. 1904. La perforación astragaliana en los mamíferos no es un carácter originariamente primitivo. Anales del Museo Nacional de Buenos Aires 3: 349-460.

Ameghino, F. 1906. Les formations sédimentaires du crétacé supérieur et du tertiaire de Patagonie avec un parallèle entre leurs faunes mammalogiques et celles de l'ancien continent. Anales del Museo Nacional de Buenos Aires 3: 1-568.

Berqvist, L. 1996. Reassociação do pós-crânio às espécies de ungulados da bacia de S.J. de Itaboraí (Paleoceno), estado do Rio de Janeiro, e filogenia dos "condylarthra" e ungulados SulAmericanos com base no pós-crânio. Ph.D thesis, Universidade Federal do Rio Grande do Sul, Porto Alegre, Brazil.

Carrano, M.T. 1997. Morphological indicators of foot posture in mammals: a statistical and biomechanical analysis. Zoological Journal of the Linnean Society 121: 77-104.

Chaffee, R.G. 1952. The Deseadan vertebrate fauna of the Scarritt Pocket, Patagonia. Bulletin of the American Museum of Natural History 98: $509-562$.

Cifelli, R.L. 1983. Eutherian tarsals from the late Paleocene of Brazil. American Museum Novitates 2761: 1-31.

Cifelli, R.L. 1985. Biostratigraphy of the Casamajoran, early Eocene. American Museum Novitates 2820: 1-26.

Cifelli, R.L. 1993. The phylogeny of the native South American ungulates. In F.S. Szalay, M.J. Novacek, and M.C. McKenna (editors), Mammal phylogeny: placentals: 195-216. New York: Springer-Verlag.

Croft, D.A. 2001. Cenozoic environmental change in South America as indicated by mammalian body size distributions (cenograms). Diversity and Distributions 7: 271-287.

Flynn, J.J., and C.C. Swisher III. 1995. Cenozoic South American Land Mammal Ages: correla- tion to global geochronologies. In W.A. Berggren, D.V. Kent, M.-P. Aubry, and J. Hardenbol (editors), Geochronology, time scales, and global stratigraphic correlation. SEPM (Society for Sedimentary Geology) Special Publication 54: 317-333.

Flynn, J.J., A.R. Wyss, D.A. Croft, and R. Charrier. 2003. The Tinguiririca Fauna, Chile: biochronology, paleoecology, biogeography, and a new earliest Oligocene South American Land Mammal "Age". Palaeogeography, Palaeoclimatology, Palaeoecology 195: 229-259.

Gaudry, A. 1906. Fossiles de Patagonie: étude sur une portion du monde antarctique. Annales de Paléontologie 1: 101-143.

Ginsburg, L. 1961. Plantigrady and digitgrady in the fissiped carnivores. Mammalia 25: 1-21.

Janis, C. 1995. Correlations between craniodental morphology and feeding behavior in ungulates: reciprocal illumination between living and fossil taxa. In J.J. Thomason (editor), Functional morphology in vertebrate paleontology: 76-98. New York: Cambridge University Press.

Kay, R.F., R.H. Madden, M.G. Vucetich, A.A. Carlini, M.M. Mazzoni, G.H. Re, M. Heizler, and H. Sandeman. 1999. Revised geochronology of the Casamayoran South American Land Mammal Age: climatic and biotic implications. Proceedings of the National Acadamy of Science 96(23): 13235-13240.

Kennett, J.P. 1977. Cenozoic evolution of Antarctic galaciation, the circum-Antarctic Ocean, and their impact on global paleoceanography. Journal of Geophysical Research 82: 3843-3860.

Lawver, L.A., and L.M. Gahagan. 2003. Evolution of Cenozoic seaways in the circum-Antarctic region. Palaeogeography, Palaeoclimatology, Palaeoecology 198: 11-37.

Loomis, F.B. 1914. The Deseado Formation of Patagonia. Concord, NH: Rumford Press.

Marshall, L.G., and R.L. Cifelli. 1990. Analysis of changing diversity patterns in Cenozoic land mammal age faunas, South America. Palaeovertebrata 19: 169-210.

Marshall, L.G., T. Sempere, and R.F. Butler. 1997. Chronostratigraphy of the mammal-bearing Paleocene of South America. Journal of South American Earth Sciences 10(1): 49-70.

Matthew, W.D. 1937. Paleocene faunas of the San Juan Basin, New Mexico. Transactions of the American Philosophical Society 30: 1-510.

O'Leary, M., and K.D. Rose. 1995. Postcranial skeleton of the early Eocene mesonychid Pachyaena (Mammalia: Mesonychia). Journal of Vertebrate Paleontology 15(2): 401-430.

Osborn, H.F. 1889. The evolution of the ungulate foot. Transactions of the American Philosophical Society 16: 531-569. 
Pascual, R., and E. Ortiz. 1990. Evolving climates and mammal faunas in Cenozoic South America. Journal of Human Evolution 19: 23-60.

Patterson, B., and R. Pascual. 1972. The fossil mammal fauna of South America. In A. Keast. F.C. Erk, and B. Glass (editors). Evolution, mammals, and southern continents: 247-309. Albany: State University of New York Press.

Prothero, D.R. 1994. The Eocene-Oligocene transition: paradise lost. New York: Columbia University Press.

Prothero, D.R., and W.A. Berggren (editors). 1992. Eocene-Oligocene climatic and biotic evolution. Princeton, NJ: Princeton University Press.

Radinsky, L.B. 1966. The adaptive radiation of the phenecodontid condylarths and the origins of perissodactyls. Evolution 20: 408-417.

Roth, S. 1899. Aviso preliminary sobre mamíferos Mesozóicos encontrados en Patagonia. Revista del Museo de La Plata 9: 38 I-388.

Schaeffer, B. 1947. Notes on the origin and function of the artiodactyl tarsus. American Museum Novitates 1356: 1-24.

Scott, W.B. 1912a. Mammalia of the Santa Cruz Beds. Vol. VI, Paleontology, Part II. Toxodonta. In W.B. Scott (editor), Reports of the Princeton University expeditions to Patagonia, 1896-1899: 239-300. Stuttgart: E. Schweizerbart'sche Verlagshandlung (E. Nägele).

Scott. W.B, 1912b. Mammalia of the Santa Cruz Beds. Vol. VI, Paleontology. Part III, Entelonychia. In W.B. Scott (editor), Reports of the Princeton University Expeditions to Patagonia. 1896-1899: 111-238. Stuttgart: E. Schweizerbart'sche Verlagshandlung (E. Nägele).

Scott, W.B. 1930. A partial skeleton of Homalodontotherium from the Santa Cruz beds of Patagonia. Memoirs of the Field Museum of Natural History 50: 1-39.

Shockey, B.J. 1997. Two new notoungulates (Family Notohippidae) from the Salla Beds of Bolivia (Deseadan: late Oligocene): systematics and functional morphology. Journal of Vertebrate Paleontology 17: 584-599.

Shockey, B.J., D.A Croft, and F. Anaya. 2007. Analysis of function in the absence of extant functional homologues: a case study using mesotheriid notoungulates (Mammalia). Paleobiology 33(2); 228-248.

Shockey, B.J., R. Salas, R. Quispe, A. Flores, E.J. Sargis, I. Acosta, A. Pino, N. Jarica, and M. Urbino. 2006. Discovery of Deseadan fossils in the upper Moquegua Formation (late Oligocene-?early Miocene) of southern Perú. Journal of Vertebrate Paleontology 26: 205-208.

Simpson, G.G. 1934. Provisional classification of extinct South American hoofed mammals. American Museum Novitates 750: 1-21.
Simpson, G.G. 1935. An animal from a lost world. Natural History: The Journal of the American Museum of Natural History 36: 316-318.

Simpson, G.G. 1936a. Skeletal remains and restoration of Eocene Entelonychia from Patagonia. American Museum Novitates 862: 1-12.

Simpson, [G].G. (printed as "Jorge Gaylord Simpson"). 1936b. Notas sobre los mamiferos mas antiguos de la colección Roth. Instituto del Museo de la Universidad Nacional de La Plata, Obra del Cincuentenario 2: 63-94.

Simpson, G.G. 1940. Review of the mammalbearing Tertiary of South America. Proceedings of the American Philosophical Society 83(5): $649-709$.

Simpson, G.G. 1948, The beginning of the age of mammals in South America. Part 1. Bulletin of the American Museum of Natural History 91(1): 1-232.

Simpson, G.G. 1967. The beginning of the age of mammals in South America. Part 2. Bulletin of the American Museum of Natural History 137 : 1-259.

Simpson, G.G. 1984. Discovers of the lost world: an account of some of those who brought back to like South American mammals long buried in the abyss of time. New Haven, CT: Yale University Press.

Sinclair, W.J. 1909. Mammalia of the Santa Cruz Beds, Vol, VI, Paleontology. Part I, Typotheria. In W.B. Scott (editor), Reports of the Princeton University expeditions to Patagonia, 1896-1899: 1-110. Stuttgart: E. Schweizerbart'sche Verlagshandlung ( $\mathrm{E}$. Nägele).

Sydow, H. 1988. Postcranial skeleton of Trachytherws (Mammalia, Notoungulata) with an evaluation of dentition. Unpublished Master's thesis, University of Florida, Gainesville.

Szalay, F, 1966. The tarsus of the Paleocene lepticid Prodiacodon (Insectivora, Mammalia). American Museum Novitates 2267: 1-13.

Van Valkenburgh, B. 1987. Skeletal indicators of locomotor behavior in living and extinct carnivores. Journal of Vertebrate Paleontology 7: 162-182.

Wang, X. 1993. Transformation from plantigrady to digitigrady: functional morphology of locomotion in Hesperocyon (Canidae: Carnivora). American Museum Novitates 3069: 1-26.

Wortman, J.L. 1894. Osteology of Patriofelis, a middle Eocene creodont. Bulletin of the American Museum of Natural History 6: 129-164.

Wyss, A.R., Flynn, J.J., Norell, M.A., Swisher III, C.C., Novacek, M.J., McKenna, M.C, and Charrier, R. 1994. Paleogene mammals from the Andes of central Chile: a preliminary taxonomic, biostratigraphic, and geochronologic assessment. American Museum Novitates 3098: 1-31. 

Complete lists of all issues of the Novitates and the Bulletin are available at World Wide Web site http://library.amnh.org/pubs. Inquire about ordering printed copies via e-mail from scipubs@amnh.org or via standard mail from: American Museum of Natural History, Library-Scientific Publications, Central Park West at 79th St., New York, NY 10024. TEL: (212) 769-5545. FAX: (212) 769-5009.

(2) This paper meets the requirements of ANSI/NISO Z39.48-1992 (Permanence of Paper). 